\title{
Genetically Engineered Mouse Models of K-Ras-Driven Lung and Pancreatic Tumors: Validation of Therapeutic Targets
}

\author{
Matthias Drosten, Carmen Guerra, and Mariano Barbacid \\ Molecular Oncology Programme, Centro Nacional de Investigaciones Oncológicas (CNIO), E-28029 Madrid, \\ Spain \\ Correspondence: mdrosten@cnio.es; mcguerra@cnio.es; mbarbacid@cnio.es
}

\begin{abstract}
$K-R A S$ signaling has been intensely studied for over 40 years. Yet, as of today, no drugs have been approved to treat $K-R A S$ mutant cancers. Since the turn of the century, scientists have used genetically engineered mouse (GEM) models to reproduce $K-R A S$ mutant cancers in a laboratory setting to elucidate those molecular events responsible for the onset and progression of these tumors and to identify suitable therapies. In this review, we outline a brief description of available GEM models for two tumor types known to be driven by $K-R A S$ mutations: lung adenocarcinoma and pancreatic ductal adenocarcinoma. In addition, we summarize a series of studies that have used these GEM tumor models to validate, either by genetic or pharmacological approaches, the therapeutic potential of a variety of targets, with the ultimate goal of translating these results to the clinical setting.
\end{abstract}

aturation analysis of more than 4700 human Stumors has identified more than 200 bona fide cancer genes (Lawrence et al. 2014). Among the five cancer genes most frequently mutated appears to be $K-R A S$, an oncogene mutated in more than a quarter of all human tumors. $K-R A S$ mutations are not equally distributed. They appear in pancreatic ductal adenocarcinoma (PDAC) $(>90 \%)$, colorectal carcinoma (45\%), lung adenocarcinoma (LAC) (25\%), and endometrial carcinoma (15\%) with lower incidence rates in several other tumor types (Pylayeva-Gupta et al. 2011; Eser et al. 2014). U.S. estimates for 2016 alone indicate that there will be more than 330,000 new cases and close to 120,000 deaths caused by K-RAS mutant pancreatic and lung tumors, two tumor types in which experimental evidence indicates that these mutations are the initiating events of the neoplastic process.

K-RAS signaling has been intensely studied for over 40 years. These studies have revealed that the main signaling pathways that convey $K-R A S$ oncogenic activity are kinase cascades that could be amenable to interference with selective inhibitors. Yet, as of today, not a single targeted drug has been approved to treat $K-R A S$ mutant cancers. Thus, it is essential to get a better understanding about K-RAS signaling and to develop experimental systems in which scientists can test novel therapeutic strategies that can be eventually translated to the clinic.

Since the turn of the century, scientists have focused on the generation of genetically engi-

Editors: Linda VanAelst, Julian Downward, and Frank McCormick

Additional Perspectives on Ras and Cancer in the 21st Century available at www.perspectivesinmedicine.org

Copyright (C) 2018 Cold Spring Harbor Laboratory Press; all rights reserved; doi: 10.1101/cshperspect.a031542

Cite this article as Cold Spring Harb Perspect Med 2018;8:a031542 
M. Drosten et al.

neered mouse (GEM) models of K-RAS mutant cancer that faithfully reproduce the natural history of the human disease. Most of these models carry endogenous mutations in those loci known to be the key drivers in human cancer such as K-Ras, p53, Ink4a/Arf, Lkbl, Pten, etc. In this review, we summarize current information regarding available GEM models for two tumor types known to be driven by $K-R A S$ mutations, LAC, and PDAC. In addition, we summarize those studies that have used these GEM tumor models to validate, either by genetic or pharmacological approaches, the therapeutic potential of selected targets with the ultimate goal of translating these results to the clinical setting.

\section{MOUSE MODELS OF $K$-RAS MUTANT LUNG ADENOCARCINOMA}

Several laboratories have developed GEM models that faithfully reproduce human LAC by introducing oncogenic mutations into resident $K$-Ras alleles. These GEM models allow systematic and reproducible interrogation of the therapeutic properties of suspected targets using sophisticated genetic strategies. However, although these GEM models often recapitulate the natural history and histologic properties of human tumors, in general, they display a more limited mutational complexity than those human tumors they are intended to model (McFadden et al. 2016).

The first GEM model of $K-R A S$ mutant LAC was developed by Jacks, Tuveson, and colleagues by generating mutant $K$-Ras alleles, designated as $K-R_{a s}{ }^{\mathrm{LA} 1}$ and $K-\mathrm{Ras}^{\mathrm{LA} 2}$, which after spontaneous somatic recombination encoded a functional $\mathrm{K}-\mathrm{Ras}^{\mathrm{G} 12 \mathrm{D}}$ oncoprotein (Johnson et al. 2001). These mice developed LACs with $100 \%$ incidence as well as thymic lymphomas and papillomas with reduced prevalence. Soon thereafter, these investigators developed a more sophisticated model that expressed an endogenous $K-$ Ras $^{\text {G12D }}$ allele ( $K$-Ras ${ }^{\text {LSLG12D }}$ ) in a temporally and spatially controllable manner by Cre-mediated recombination (Jackson et al. 2001). Selective activation of K-Ras ${ }^{\mathrm{G} 12 \mathrm{D}}$ expression in lung tissue can be easily accomplished by intranasal instillation or intratracheal in- fection with adenoviral particles expressing the Cre recombinase. A similar strain carrying a G12V mutation was generated in our laboratory (Guerra et al. 2003). This strain, $\mathrm{K}-\mathrm{Ras}^{+/ \mathrm{LSLG} 12 \mathrm{Vgeo}}$, also carries sequences that encode a bacterial protein (geo) that provides $\beta$-galactosidase activity that serves as a color marker (Guerra et al. 2003). Intratracheal infection with adenoviral particles yields results very similar to those reported by Tuveson, Jacks, and coworkers. More recently, Jacks and colleagues have generated a variant of their $\mathrm{K}-\mathrm{Ras}^{+/ \mathrm{LSLG} 12 \mathrm{D}}$ strain in which the loxP sites flanking the transcriptional termination element were replaced by frt sequences (Young et al. 2011). This strain, $K-$ Ras $^{+/ F S F G 12 D}$, allows uncoupling of oncogene expression (mediated by the yeast Flp recombinase) from target inactivation or any other genetic manipulation that relies on the use of the Cre recombinase. It is worth mentioning that Varmus and colleagues developed another transgenic model by generating a strain that expressed the K-Ras4b ${ }^{\text {G12D }}$ isoform in alveolar type II cells under the control of a doxycyline response element (Spc-rtTAtetO-K-RAS4b ${ }^{G 12 D}$ ) (Fisher at al. 2001). This model gives rise to LACs similar to the GEM strains described above, and has also been used to show that these tumors require continuous expression of the K-Ras $4 b^{\text {G12D }}$ oncoprotein for maintenance.

Although all strains described above develop LACs that are highly reminiscent of human tumors, human LACs carry additional oncogenic insults that result in more aggressive neoplasias that are likely to alter therapeutic responses (Skoulidis et al. 2015). Some of these cooperating oncogenic insults have also been modeled in GEM models of $K$-Ras LAC by concomitantly ablating tumor suppressor genes such as $p 53$ (Jackson et al. 2005), Ink4a/Arf (Ji et al. 2007), or Lkb1 (Ji et al. 2007). Loss of p53 or expression of mutant $p 53$ alleles causes lung tumors to progress much more rapidly and eventually yield metastatic lesions (Jackson et al. 2005). Similar results were obtained by deletion of the Ink4a/Arflocus. Ablation of $L k b 1$ caused tumors to progress even faster and to metastasize with higher incidence (Ji et al. 2007). 


\section{TARGET VALIDATION: TUMOR INITIATION MODELS}

GEM tumor models were first used to genetically validate targets of potential therapeutic interest by knocking-out candidate genes in the germline (providing they did not significantly affect viability) or by using conditional floxed alleles that were ablated concomitantly with the induction of $K$-Ras oncogene expression (Kwon and Berns 2013; Drosten and Barbacid 2016). Thus, the observed therapeutic responses may have limited clinical applicability, because the requisites to block tumor initiation are likely to be far less stringent than those necessary to induce tumor regression (Drosten and Barbacid 2016). The majority of these studies have focused on targets that are thought to play a role as K-Ras downstream effector molecules such as the members of the mitogen-activated protein kinase (MAPK) pathway (Raf, Mek, and Erk kinases, Etv5, Jnk, Cdk4, Smyd3), other Ras-like molecules (Ral, Rac) or metabolic enzymes (Acsl, Siva, Hk2, Cox2). Other studies have validated targets known to be involved in the Notch (Notch1, Psen1, Psen2, Rbpj), NF$\kappa \mathrm{B}(\mathrm{I \kappa} \mathrm{B} \alpha, \mathrm{p} 65 / \operatorname{RelA}, \mathrm{Ikk} \beta)$, or PI3K (p110 $\alpha$, p $85 \alpha$, p $85 \beta$, mTRAIL-R) pathways. Genes encoding targets involved in other cellular processes such as ribosomal RNA (rRNA) synthesis (Ect2), telomere elongation (Trf1), senescence prevention (Wt1), and control of cell proliferation (Fadd, Csn1k1, Foxm1) have also been validated (Table 1). Altogether, these studies have helped to unravel mechanisms implicated in the early steps of tumor development. Because of space limitations, they will not be discussed in this review but they are listed in Table 1 .

\section{TARGET VALIDATION: THERAPEUTIC MODELS}

\section{K-Ras ${ }^{\text {LA2 }}$ Model}

This model develops spontaneous tumors. Hence, target validation can be performed using floxed alleles that can be inactivated on activation of a Cre recombinase in tumorbearing animals (Table 2). Downward and col- leagues used a conditional $P i k 3 c a^{\text {RBDlox }}$ allele that on Cre-mediated recombination expresses a p110 $\alpha$ PI3K subunit defective in Ras binding (Castellano et al. 2013). Acute expression of this p110 $\alpha$ mutant isoform in established $K-$ Ras $^{\mathrm{G} 12 \mathrm{D}}$ lung tumors caused long-term tumor stasis and, in some cases, partial regression (Castellano et al. 2013). The same laboratory also identified a requirement for the Gata2 transcriptional network. Conditional elimination of Gata2 from established lung tumors led to near-complete tumor regression rates (Kumar et al. 2012). The same model was also used to ablate Hexokinase 2 from established tumors causing reduced tumor progression rates (Patra et al. 2013).

\section{K-Ras ${ }^{\text {LSLG12D }}$ and K-Ras ${ }^{\text {LSLG12Vgeo }}$ Models}

Since these models rely on the Cre recombinase for tumor induction, they are not particularly well suited to validate therapeutic targets in preexisting tumors because target ablation often relies on the Cre/loxP system. However, there are some examples in which target inactivation was performed by different experimental approaches. For instance, the $K-R^{+} s^{+/ L S L G 12 D}$ strain was used to validate Myc by expressing a dominant-negative peptide (Omomyc) using a doxycycline-dependent expression system (Soucek et al. 2008). Induction of Omomyc expression led to overt tumor regression even in aggressive tumors driven by mutant K-Ras expression and p53 ablation without significant toxicity under conditions of controlled Omomyc expression (Soucek et al. 2013). This model was also used to block the NF- $\mathrm{KB}$ pathway by infecting $K-$ Ras $^{+/ \text {LSLG12D }_{p}} ; p 53^{\text {lox/lox }}$ mice with a lentivirus that expressed a dominant negative ІкB $\alpha$ super repressor under the control of a doxycycline-inducible promoter. Tumors still grew but at a lower rate than in control mice (Meylan et al. 2009). Finally, Tran et al. (2012) observed tumor stasis when they reduced Twist1 expression in $\mathrm{K}-\mathrm{Ras}^{+/ \mathrm{LSLG12D}}$ mice carrying advanced lung tumors using a doxycyclinedependent transgene. Finally, the related $\mathrm{K}$ $\mathrm{Ras}^{+/ \text {LSLG12Vgeo }}$ model has been used to validate the therapeutic effect of Cdk4 by using con- 
M. Drosten et al.

Table 1. Target validation in tumor initiation models driven by K-Ras oncogenes

\begin{tabular}{|c|c|c|c|}
\hline Model & Target(s) & Tumor phenotype & References \\
\hline$\overline{K-R^{+} s^{+/ \mathrm{LA} 2}}$ & $p 110 \alpha^{\text {RBDmut/RBDmut }}$ & No tumor development & Castellano et al. 2013 \\
\hline$K-\mathrm{Ras}^{+/ \mathrm{LSLG12D}}$ & $c-R a f^{\mathrm{dox} / \mathrm{lox}}$ & No tumor development & Karreth et al. 2011 \\
\hline$K-\operatorname{Ras}^{+/ \mathrm{LSLG12D}}$ & $\operatorname{RalA}^{\text {lox } / \text { lox }} ;$ RalB $^{-/-}$ & No tumor development & Peschard et al. 2012 \\
\hline$K-\operatorname{Ras}^{+/ L S L G 12 D}$ & $\operatorname{Rac1} 1^{\operatorname{lox} / \operatorname{lox}}$ & No tumor development & Kissil et al. 2007 \\
\hline$K-$ Ras $^{+/ L S L G 12 D}$ & $J n k 1^{\text {lox } / \operatorname{lox}} ; J n k 2^{-/-}$ & No tumor development & Cellurale et al. 2011 \\
\hline$K-R_{a s}^{+/ L S L G 12 D}$ & $E t v 5^{\text {lox } / \text { lox }}$ & No tumor development & Zhang et al. 2017 \\
\hline$K-$ Ras $^{+/ \text {LSLG12D }}$ & $P i k 3 r 1^{\text {lox/lox }} ; P i k 3 r 2^{-/-}$ & Decreased tumor development & Engelman et al. 2008 \\
\hline$K-\operatorname{Ras}^{+/ \text {LSLG12D }}$ & Notch $1^{\text {lox } / \text { lox }}$ & Decreased tumor development & Licciulli et al. 2013 \\
\hline$K-\operatorname{Ras}^{+/ \mathrm{LSLG} 12 \mathrm{D}}$ & $W t 1^{\operatorname{lox} / \operatorname{lox}}$ & Decreased tumor development & Vicent et al. 2010 \\
\hline$K-$ Ras $^{+/ \text {LSLG12D }}$ & Fadd $d^{\operatorname{lox} / \operatorname{lox}}$ & Decreased tumor development & Bowman et al. 2015 \\
\hline$K-$ Ras $^{+/ L S L G 12 D}$ & $\operatorname{Csn} 1 k 1^{\mathrm{lox} / \mathrm{lox}}$ & Decreased tumor development & Bowman et al. 2015 \\
\hline$K-$ Ras $^{+/ L S L G 12 D}$ & Siva $a^{\operatorname{lox} / \mathrm{lox}}$ & Decreased tumor development & $\begin{array}{l}\text { Van Nostrand et al. } \\
2015\end{array}$ \\
\hline$K-$ Ras $^{+/ \text {LSLG12D }}$ & Smyd3 $3^{-1-}$ & Decreased tumor development & Mazur et al. 2014 \\
\hline$K-\operatorname{Ras}^{+/ L S L G 12 D}$ & $A c s l 3^{-1-}$ & Decreased tumor development & Padanad et al. 2016 \\
\hline K-Ras ${ }^{+/ L S L G 12 D}$ & $\operatorname{Cox} 2^{-1-}$ & Decreased tumor development & Pan et al. 2015 \\
\hline$K-R_{a s}+/$ LSLG12D & $H k 2^{\operatorname{lox} / \operatorname{lox}}$ & Decreased tumor development & Patra et al. 2013 \\
\hline$K-\operatorname{Ras}^{+/ L S L G 12 \mathrm{D}} ; p 53^{\mathrm{lox} / \mathrm{lox}}$ & DN-IкB $\alpha$ (Tet-On) & Decreased tumor development & Meylan et al. 2009 \\
\hline$K-\operatorname{Ras}^{+/ L S L G 12 D} ; p 53^{\operatorname{lox} / \mathrm{lox}}$ & $p 65^{\operatorname{lox} / \operatorname{lox}}$ & Decreased tumor development & Bassères et al. 2010 \\
\hline K-Ras ${ }^{+/ L S L G 12 D} ; p 53^{\operatorname{lox} / \operatorname{lox}}$ & $E c t 2^{\operatorname{lox} / \mathrm{lox}}$ & Decreased tumor development & Justilien et al. 2017 \\
\hline$K-\operatorname{Ras}^{+/ \text {LSLG12D }} ; p 53^{\operatorname{lox} / \mathrm{lox}}$ & $\operatorname{Trk} b^{\operatorname{lox} / \operatorname{lox}}$ & Reduced metastasis & Sinkevicius et al. 2014 \\
\hline K-Ras ${ }^{+/ \text {LSLG12D }} ; p 53^{+/ \text {LSLR172H }}$ & $m T R A I L-R^{\mathrm{lox} / \mathrm{lox}}$ & Decreased tumor development & $\begin{array}{l}\text { von Karstedt et al. } \\
\quad 2015\end{array}$ \\
\hline K-Ras ${ }^{+/ L S L G 12 D} ; s h-p 53$ & $I k k \beta^{\operatorname{lox} / \operatorname{lox}}$ & Decreased tumor development & Xia et al. 2012 \\
\hline$K-$ Ras $^{+/ \text {LSLG12Vgeo }}$ & $c-R a f^{\mathrm{dox} / \mathrm{lox}}$ & No tumor development & Blasco et al. 2011 \\
\hline$K-$ Ras $^{+/ \text {LSLG12Vgeo }}$ & $\operatorname{Mek} 1^{\operatorname{lox} / \operatorname{lox}} ; M e k 2^{-/-}$ & No tumor development & Blasco et al. 2011 \\
\hline$K-$ Ras $^{+/ \text {LSLG12Vgeo }}$ & $E r k 1^{-/-} ; E r k 2^{\operatorname{lox} / \operatorname{lox}}$ & No tumor development & Blasco et al. 2011 \\
\hline$K-$ Ras $^{+/ \text {LSLG12Vgeo }}$ & $C d k 4^{-/-}$ & No tumor development & Puyol et al. 2010 \\
\hline$K-$ Ras $^{+/ \text {LSLG12Vgeo }}$ & $P \operatorname{sen} 1^{\text {lox/lox}} ; P \operatorname{sen} 2^{-/-}$ & Decreased tumor development & Maraver et al. 2012 \\
\hline$K-$ Ras $^{+/ \text {LSLG12Vgeo }}$ & $R b p j^{\text {lox } / \text { lox }}$ & Decreased tumor development & Maraver et al. 2012 \\
\hline K-Ras ${ }^{+/ \text {LSLG12Vgeo }} ; p 53^{-/-}$ & $\operatorname{Trf} 1^{\operatorname{lox} / \operatorname{lox}}$ & Decreased tumor development & $\begin{array}{l}\text { García-Beccaria et al. } \\
2015\end{array}$ \\
\hline Tet-op-K-Ras4b $b^{\mathrm{G} 12 \mathrm{D}}$ & Foxm $1^{\text {lox/lox }}$ & Decreased tumor development & Wang et al. 2014 \\
\hline
\end{tabular}

ditional $C d k 4^{\text {frt }}$ alleles (Puyol et al. 2010). However, this approach is not recommended because the Flp recombinase is less efficient than the bacterial Cre recombinase, resulting in limited target ablation.

\section{Spc-rtTA-tetO-K-RAS4b ${ }^{\text {G12D }}$ Model}

In this model, the $\mathrm{K}-\mathrm{Ras} 4 \mathrm{~b}$ protein is selectively expressed in lung tissue (mainly SP-C ${ }^{+}$AT2 cells) on treatment with doxycycline (Fisher et al. 2001). Once the tumors are formed, targets to be validated can be ablated by incorporating their corresponding floxed alleles along with an inducible CreERT2 recombinase followed by exposure to tamoxifen (Tam). This model has been used to show that ablation of the metabolic enzyme lactate dehydrogenase A caused limited regression of K-Ras ${ }^{\mathrm{G} 12 \mathrm{D}}$ induced tumors (Xie et al. 2014).

\section{K-Ras ${ }^{+/ \text {FSFG12D }}$ Model}

This tumor model allows tumor induction on expression of the Flp recombinase in lung tissue, most frequently via intranasal instillation or intratracheal infection with adenoviral particles. Once tumors are formed, targets can be 
Mouse Models of K-Ras-Driven Tumors for Target Validation

Table 2. Target validation in established $K$-Ras-driven lung adenocarcinomas

\begin{tabular}{|c|c|c|c|c|}
\hline Model & Target & Tumor phenotype & Systemic toxicity & References \\
\hline$K-R_{a s}+/ \mathrm{LA} 2$ & $p 110 \alpha^{\text {RBDlox/- }}$ & $\begin{array}{l}\text { Tumor stasis and partial } \\
\text { regression }\end{array}$ & $\begin{array}{l}\text { No significant } \\
\text { toxicity }\end{array}$ & $\begin{array}{l}\text { Castellano et al. } \\
2013\end{array}$ \\
\hline$K-R_{a s}+/ \mathrm{LA} 2$ & Gata2 $2^{\operatorname{lox} / \mathrm{lox}}$ & $\begin{array}{l}\text { Regression of established } \\
\text { tumors }\end{array}$ & $\begin{array}{l}\text { No significant } \\
\text { toxicity }\end{array}$ & Kumar et al. 2012 \\
\hline$K-$ Ras $^{+/ L S L G 12 D}$ & $\begin{array}{l}\text { Omomyc } \\
(\mathrm{c}-\mathrm{Myc})\end{array}$ & $\begin{array}{l}\text { Long-term tumor } \\
\text { eradication }\end{array}$ & Reversible toxicity & Soucek et al. 2013 \\
\hline$K-\operatorname{Ras}^{+/ L S L G 12 D}$ & Twist1 (Tet-On) & Tumor stasis, senescence & $\mathrm{ND}^{\mathrm{a}}$ & Tran et al. 2012 \\
\hline $\begin{array}{c}\text { K-Ras }{ }^{+/ \text {LSLG12D }} ; \\
p 53^{\text {ER/ER }}\end{array}$ & $\begin{array}{l}\text { Omomyc } \\
(\mathrm{c}-\mathrm{Myc})\end{array}$ & $\begin{array}{l}\text { Long-term tumor } \\
\text { eradication }\end{array}$ & Reversible toxicity & Soucek et al. 2013 \\
\hline $\begin{array}{c}\text { K-Ras } \\
p 53^{\text {lox } / \text { lox }}\end{array}$ & $\begin{array}{l}\text { DN-IкB } \alpha \\
\quad(\text { Tet-On) }\end{array}$ & $\begin{array}{l}\text { Inhibition of tumor } \\
\text { progression, apoptosis }\end{array}$ & ND & Meylan et al. 2009 \\
\hline K-Ras ${ }^{+/ L S L G 12 V g e o ~}$ & $C d k 4^{\mathrm{frt} / \mathrm{frt}}$ & $\begin{array}{l}\text { Inhibition of tumor } \\
\text { progression }\end{array}$ & $\begin{array}{l}\text { No significant } \\
\text { toxicity }\end{array}$ & Puyol et al. 2010 \\
\hline Tet-op-K-Ras $4 b^{\mathrm{G} 12 \mathrm{D}}$ & $L d h a^{\operatorname{lox} / \operatorname{lox}}$ & $\begin{array}{l}\text { Inhibition of tumor } \\
\text { progression }\end{array}$ & Nonlethal anemia & Xie et al. 2014 \\
\hline $\begin{array}{c}K-R a s^{+/ F S F G 12 D} ; \\
p 53^{\text {frt/frt }}\end{array}$ & $\operatorname{Atg} 7^{\text {lox } / \operatorname{lox}}$ & $\begin{array}{l}\text { Inhibition of tumor } \\
\text { progression }\end{array}$ & Long-term toxicity & $\begin{array}{l}\text { Karsli-Uzunbas } \\
\text { et al. } 2014\end{array}$ \\
\hline
\end{tabular}

${ }^{\mathrm{a}} \mathrm{ND}$, Not determined.

validated by using conditional floxed alleles along with an inducible CreERT2 recombinase activated by exposure to Tam or by using inducible Cre transgenes. White and coworkers have used this model, including conditional $p 53^{\text {frt }}$ alleles (Lee et al. 2012), to show that the autophagy-related protein Atg7 was required for progression of $K$-Ras $/ p 53$-driven LAC tumors (Karsli-Uzunbas et al. 2014).

\section{PHARMACOLOGICAL STUDIES}

GEM tumor models, if properly designed, closely recapitulate the natural history of those human tumors they try to model. The fact that GEM tumors are initiated by the same endogenous mutations responsible for their human counterparts also serve as an excellent tool to validate pharmacological approaches before they are translated to the clinic. Indeed, GEM tumor models have proven their value in mouse coclinical trial platforms, where mice are subjected to experimental protocols that mirror clinical trials in human patients (Clohessy and Pandolfi 2015).

Johnson and colleagues have treated $K$ Ras $^{+/ \text {LSLG12D }} ;$ $53^{\mathrm{frt} / \mathrm{frt}}$ mice infected with adenoviruses expressing Flp and Cre recombinases to generate aggressive LACs, which were subsequently treated with an antibody against vascular endothelial growth factor (VEGF) in combination with standard chemotherapy under experimental conditions that mirrored prior clinical trials (Singh et al. 2010). The similarity between the results obtained in the mouse tumor models with those previously observed in the clinic proved the value of these models to predict clinical outcomes (Singh et al. 2010). Another coclinical trial showed that treatment with the MEK inhibitor Selumetinib in combination with chemotherapy was beneficial only in $K-R_{a s}{ }^{+/ L S L G 12 D}$ or in compound $K-R a s^{+/ L S L G 12 D} ; p 53^{\text {lox/lox }}$ mice, but not in $K-R a s^{+/ L_{L S G 12 D}} ; L k b 1^{\text {lox/lox }}$ animals, thus indicating that loss of Lkb1 modified the therapeutic response (Chen et al. 2012). The same group has further shown that blocking two of the most relevant K-Ras downstream pathways with MEK and PI3K inhibitors resulted in synergistic shrinkage of lung tumors in $\mathrm{K}-\mathrm{Ras}^{+/ \text {LSLG12D }}$ mice (Engelman et al. 2008). Another study has shown that combining the MEK inhibitor Trametinib with inhibition of FGFR1 was also effective in $K$-Ras ${ }^{+/ L S L G 12 D} ; p 53^{-/-}$tumors (Manchado et al. 2016). Unfortunately, the differential tolerance of rodents and humans 
M. Drosten et al.

to MEK inhibitors have limited the clinical applicability of these studies.

Other investigators have reported that metastases from $K$-Ras ${ }^{+/ L S L G 12 D} ; L k b 1^{\text {lox } / \text { lox }}$ mice showed increased Src signaling and that combination of MEK, PI3K, and SRC inhibitors was able to cause regression of these metastasis (Carretero et al. 2010). In another study, Scaglioni and colleagues observed that loss of Ink $4 a / A r f$ caused aberrant signaling through RhoA and FAK in $K$-Ras ${ }^{+/ \text {LSLG12D }}$ mice (Konstantinidou et al. 2013). Treatment with the FAK inhibitor PF562271 caused regression of lung tumors in $\mathrm{K}$-Ras ${ }^{+/ L_{S L G 12 D}} ;$ Ink $4 a /$ $A r f^{-1}$ mice, but not of those initiated in K-Ras ${ }^{+/ L S L G 12 D}$ mice. Work from our laboratory has identified DDR1 as a promising target by focusing on genes induced during the earliest stages of tumor development (Ambrogio et al. 2016). Pharmacological treatment of established $K$-Ras/p53-driven lung tumors with a DDR1 inhibitor in combination with a Notch inhibitor, a pathway activated by DDR1, resulted in significant tumor regression with less toxic effects that standard chemotherapy.

More recently, the particular metabolic requirements of K-Ras mutant LAC were also exploited pharmacologically. Shaw and colleagues have shown that blocking fatty acid oxidation by pharmacologically blocking the enzyme Acetyl-CoA carboxylase with an allosteric inhibitor suppressed growth of tumors derived from both $K-$ Ras $^{+/ \text {LSLG12D }} ; p 53^{\text {lox } / \text { lox }}$ and $K$ $\mathrm{Ras}^{+/ \mathrm{LSLG} 12 \mathrm{D}} ; \mathrm{Lkb1} 1^{\text {lox/lox }}$ mice (Svennson et al. 2016). Similarly, Vander Heiden and coworkers have revealed increased glucose contribution to the tricarboxylic acid (TCA) cycle in K-Ras mutant lung tumors (Davidson et al. 2016). This property made inhibition of glutaminase ineffective, but suggested that inhibition of mitochondrial metabolism of pyruvate could be a beneficial strategy.

\section{MOUSE MODELS OF PDAC}

PDAC is one of the most lethal types of cancer for which there are no effective therapies available (Hidalgo 2010). Current experimental and pathological evidence suggests that PDAC stems from $K-R A S$ mutations in acinar cells. When these cells undergo acinar-ductal cell metaplasia, a physiological and reversible process, they become blocked in a ductal-like phenotype that eventually progresses to form preneoplastic lesions known as pancreatic intraepithelial neoplasias (PanINs). Indeed, these benign lesions are present in many healthy pancreata (Maitra and Hruban 2008). Unfortunately, low-grade PanINs, such as PanIN1A, can progress to more aggressive lesions such as PanIN1B and PanIN2, possibly caused by additional mutations such as loss or inactivation of the INK4a tumor suppressor (Kanda et al. 2012). These lesions further progress to yield high-grade PanIN3, considered already as a form of in situ carcinoma, as well as invasive PDAC on accumulation of additional genetic insults, mainly inactivation of other tumor suppressors such as P53, SMAD4, or BRCA2 (Maitra and Hruban 2008). During the last decade or so, several experimental models of human PDAC have been generated, most of them by engineering within the mouse genome those mutations responsible for the development of the human tumors. A brief description of the models most frequently used is described below and listed in Table 3.

\section{K-Ras ${ }^{\text {LSLG12D;Pdx1-Cre/P48-Cre Model }}$}

The first experimental model that faithfully reproduced the natural history of human PDAC in mice involved expression of an endogenous $K-R_{a s}{ }^{\mathrm{G} 12 \mathrm{D}}$ oncogene in all epithelial pancreatic lineages during early embryonic development by crossing the conditional $K-$ Ras $^{+/ \text {LSLG12D }}$ strain described above with transgenic mice expressing the Cre recombinase under the control of the $P d x 1$ - or the Ptfla/P48-specific pancreatic promoters (Hingorani et al. 2003). Both compound strains, K-Ras ${ }^{+/ L_{L}}{ }^{2 D} ; P d x 1-C r e$ or $\mathrm{K}$-Ras ${ }^{+/ L S L G 12 D}$;Ptf1a/P48-Cre, generically known as $\mathrm{KC}$ mice, develop the full spectrum of PanIN lesions and PDAC tumors histologically indistinguishable from those present in human patients (Hingorani et al. 2003). A variant of the KC mice in which the Cre recombinase is driven by a Nestin-Cre transgene has also 
Mouse Models of K-Ras-Driven Tumors for Target Validation

Table 3. Genetically engineered mouse pancreatic ductal adenocarcinoma (PDAC) models

\begin{tabular}{|c|c|c|}
\hline Driver genes(s) & Recombinase & References \\
\hline $\mathrm{K}_{- \text {Ras }^{+} / \text {LSLG12D }}$ & Pdx1-Cre & Hingorani et al. 2003 \\
\hline$K-\operatorname{Ras}^{+/ L S L G 12 D}$ & Ptfla/P48-Cre & Hingorani et al. 2003 \\
\hline$K-\operatorname{Ras}^{+/ \text {LSLG12D }}$ & Nestin-Cre & Carriere et al. 2007 \\
\hline$K-\operatorname{Ras}^{+/ \mathrm{LSLG12D}}$ & Pdx1-CreERT & Gidekel-Friedlander et al. 2009 \\
\hline$K-\operatorname{Ras}^{+/ L S L G 12 D}$ & Ela-CreER & De La O et al. 2008 \\
\hline$K-$ Ras $^{+/ \text {LSLG12D }}$ & Ela-CreERT2 & Habbe et al. 2008 \\
\hline$K-$ Ras $^{+/ \text {LSLG12D }}$ & Mist1-CreERT2 & Habbe et al. 2008 \\
\hline$K-\operatorname{Ras}^{+/ \text {LSLG12D }}$ & proCPA1-CreERT2 & Gidekel-Friedlander et al. 2009 \\
\hline$K-\operatorname{Ras}^{+/ \mathrm{LSLG} 12 \mathrm{D}} ; p 53^{+/ \mathrm{LSLR} 172 \mathrm{H}}$ & Pdx1-Cre and Ptf1a/P48-Cre & Hingorani et al. 2005 \\
\hline K-Ras ${ }^{+/ L S L G 12 D} ; p 53^{\operatorname{lox} / \operatorname{lox}}$ & Pdx1-Cre and Ptfla/P48-Cre & Bardeesy et al. 2006 \\
\hline$K-R_{a s}{ }^{+/ L S L G 12 D} ; \operatorname{Ink} 4 a / A r f^{\text {ox } / \operatorname{lox}}$ & Pdx1-Cre & Aguirre et al. 2003 \\
\hline $\mathrm{K}-\mathrm{Ras}^{+/ \mathrm{LSLG12D}} ; \mathrm{Brca}^{\text {lox } / \mathrm{lox}}$ & $P d x 1-C r e$ & Skoulidis et al. 2010 \\
\hline$K-R_{a s}^{+/ L_{S L G 12 D}} ; L k b 1^{+/ \text {lox }}$ & Pdx1-Cre & Morton et al. 2010 \\
\hline K-Ras ${ }^{+/ \text {LSLG12D }_{p}} ; \mathrm{p} 1 \mathrm{Cip} 1^{+/-}$ & Pdx1-Cre & Morton et al. 2010 \\
\hline 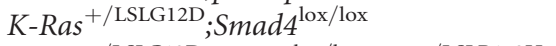 & Pdx1-Cre and Ptf1a/P48-Cre & Bardeesy et al. 2006 \\
\hline K-Ras ${ }^{+/ L S L G 12 D} ; S m a d 4^{\text {lox } / \text { lox }} ; p 53^{+/ L S L R 172 H}$ & Ptfla/P48-Cre & Whittle et al. 2015 \\
\hline K-Ras ${ }^{+/ \text {LSLG12D }} ;$ Smad4 ${ }^{\text {lox } / \text { lox }} ;$ Ink $4 a / A r f^{\text {dox } / \text { lox }}$ & Pdx1-Cre and Ptf1a/P48-Cre & Bardeesy et al. 2006 \\
\hline$K-$ Ras $^{+/ \text {LSLG12D }} ;$ TGF $\beta R I I^{\text {lox } / \text { lox }}$ & Ptfla/P48-Cre & Ijichi et al. 2006 \\
\hline K-Ras ${ }^{+/ \text {LSLG12D }} ;$ Pten $^{\text {lox } / \text { lox }}$ & Pdxl-Cre & Ying et al. 2011 \\
\hline$K-\operatorname{Ras}^{+/ L S L G 12 D} ; p 53^{\operatorname{lox} / \operatorname{lox}}$ & Pdx1-CreERT & Gidekel-Friedlander et al. 2009 \\
\hline$K-\operatorname{Ras}^{+/ L S L G 12 D} ; p 53^{\operatorname{lox} / \mathrm{lox}}$ & proCPA1-CreERT2 & Gidekel-Friedlander et al. 2009 \\
\hline$K-\operatorname{Ras}^{+/ L_{S L G 12 D}} ; \operatorname{Ink} 4 a / A r f^{\mathrm{dox} / \mathrm{lox}}$ & Pdx1-CreERT & Gidekel-Friedlander et al. 2009 \\
\hline$K-\operatorname{Ras}^{+/ \text {LSLG12D }_{2}} ; \operatorname{Ink} 4 a / A r f^{\mathrm{dox} / \mathrm{lox}}$ & proCPA1-CreERT2 & Gidekel-Friedlander et al. 2009 \\
\hline $\mathrm{K}-\mathrm{Ras}^{+/ \mathrm{LSLG} 12 \mathrm{Vgeo}}$ & Elas-tTA;Tet-O-Cre & Guerra et al. 2007 \\
\hline K-Ras ${ }^{+/ \text {LSLG12Vgeo }} ; p 53^{\text {lox } / \text { lox }}$ & Elas-tTA;Tet-O-Cre & Guerra et al. 2011 \\
\hline K-Ras ${ }^{+/ L S L G 12 V g e o} ; \operatorname{Ink} 4 a / A r f^{\text {dox/lox }}$ & Elas-tTA;Tet-O-Cre & Guerra et al. 2011 \\
\hline $\mathrm{Tet} O-K-R a s 4 b^{\mathrm{G} 12 \mathrm{D}}$ & $\begin{array}{l}\text { Ptf1a/P48-Cre;R26-LSLrtTA- } \\
\quad \text { IRES-EGFP }\end{array}$ & Collins et al. 2012 \\
\hline TetO-LSL-K-Ras $4 b^{\mathrm{G} 12 \mathrm{D}}$ & $\begin{array}{l}\text { Ptf1a/P48-Cre;R26-LSLrtTA- } \\
\quad \text { IRES-EGFP }\end{array}$ & Ying et al. 2012 \\
\hline$K-R_{a s}^{+/ F S F G 12 D}$ & $P d x 1-F l p$ & Schönhuber et al. 2014 \\
\hline$K-$ Ras $^{+/ \text {FSFG12D }}$ & $\begin{array}{l}\text { Pdxl-Flp;R26-CAG-FSF- } \\
\quad \text { CreERT2 }\end{array}$ & Schönhuber et al. 2014 \\
\hline K-Ras ${ }^{+/ \text {FSFG12D }} ; p 53^{\text {lox } / \text { lox }}$ & $\begin{array}{l}P d x 1-F l p ; R 26-C A G-F S F- \\
\quad \text { CreERT2 }\end{array}$ & Schönhuber et al. 2014 \\
\hline$K-$ Ras $^{+/ \text {FSFG12V }}$ & Elas-tTA;Tet-O-Flp & $\begin{array}{l}\text { MT Blasco, C Guerra, and M } \\
\text { Barbacid, Unpubl. }\end{array}$ \\
\hline$K-$ Ras $^{+/ \text {FSFG12V }}$ & $\begin{array}{l}\text { Elas-tTA;Tet-O-Flp; } h U B C- \\
\quad \text { CreERT2 }\end{array}$ & $\begin{array}{l}\text { MT Blasco, C Guerra, and M } \\
\text { Barbacid, Unpubl. }\end{array}$ \\
\hline$K-$ Ras $^{+/ \mathrm{FSFG}_{12 \mathrm{~V}}} ; \mathrm{p} 53^{\mathrm{frt} / \mathrm{frt}}$ & Elas-tTA;Tet-O-Flp & $\begin{array}{l}\text { MT Blasco, C Guerra, and M } \\
\text { Barbacid, Unpubl. }\end{array}$ \\
\hline$K-$ Ras $^{+/ \mathrm{FSFG}_{12 \mathrm{~V}}} ; p 53^{\mathrm{frt} / \mathrm{frt}}$ & $\begin{array}{l}\text { Elas-tTA;Tet-O-Flp; } h U B C- \\
\quad \text { CreERT2 }\end{array}$ & $\begin{array}{l}\text { MT Blasco, C Guerra, and M } \\
\text { Barbacid, Unpubl. }\end{array}$ \\
\hline
\end{tabular}

been generated (Carriere et al. 2007). Yet, the incidence of PDAC tumors in these strains is rather low, at least at 1 year of age. Additional mutations present in human tumors, including inactivation or deletion of tumor suppressors such as p53 (KPC strain), Ink4a/Arf, Brca2, Lkb1,p21Cip1, or Smad4 significantly accelerate progression of PanIN lesions to invasive PDAC and induce metastasis in a significant percentage of cases (Table 3). Similar results have 
M. Drosten et al.

been obtained on elimination of the genes encoding the transforming growth factor $\beta$ (TGF- $\beta$ ) receptor II $(T g f b r 2)$ and the Pten phosphatase (Pten) (Ijichi et al. 2006; Ying et al. 2011) (Table 3).

\section{K-Ras ${ }^{\text {LSLG12Vgeo }}$;Elas-tTA;TetO-Cre Model}

An independent GEM tumor model that also recapitulates human PDAC was generated by expressing an endogenous $\mathrm{K}-\mathrm{Ras}^{\mathrm{G} 12 \mathrm{~V}}$ oncogene in pancreatic acinar cells during late embryonic development (Guerra et al. 2007). This model,

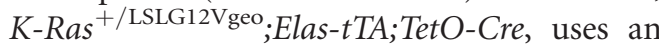
inducible Tet-Off strategy to express the Cre recombinase under the control of the elastase promoter (Guerra et al. 2007). This strain develops PanIN lesions as well as full-blown PDAC tumors with similar latencies and penetrance as the KC mice (Hingorani et al. 2003; Guerra et al. 2007). K-Ras ${ }^{+/ \text {LSLG12Vgeo }}$ Elas-tTA;TetO-Cre mice also show complete tumor penetrance and reduced survival on inactivation of the $p 53$ or Ink4a/Arf tumor suppressors (Guerra et al. 2011). This model has the advantage that Cre expression can be inhibited by doxycycline. Hence, continuous exposure of pregnant mothers and their offspring to this antibiotic prevents activation of these genetic insults. Doxycycline withdrawal at any time during postnatal development or in adult mice allows activation of $K$-Ras oncogene expression as well as ablation of the $p 53$ and/or Ink4a/Arf tumor suppressors. This strategy has been used to show that adult pancreatic acinar cells are completely resistant to transformation by the $K$-Ras oncogene even in the absence of p53 (Guerra et al. 2011). These studies have also served to show the importance of pancreatic injury in the development of PDACs in adult mice (Guerra et al. 2007, 2011).

\section{Inducible CreERT2-Based Models}

Other investigators have developed GEM models of PDAC that allow expression of $K-R a s^{\text {G12D }}$ oncogenes in adult mice by using the inducible CreERT2 recombinase driven by specific promoters. They include Ela-CreER (De La O et al. 2008), Ela-CreERT2 (Habbe et al. 2008), Mist1-CreERT2 (Habbe et al. 2008), Pdx1CreERT (Gidekel-Friedlander et al. 2009), and proCPA1-CreERT2 (Gidekel-Friedlander et al. 2009). Although these strains display differences in the incidence of PanIN development, it is clear that the susceptibility of acinar cells to $K$-Ras oncogene-induced transformation is progressively lost during postnatal development. The "age limit" for adult acinar cells to become resistant to K-Ras-induced transformation may depend on the genetic background, the expression pattern of the Cre recombinase, and the different conditional strategies.

\section{Inducible K-Ras4b ${ }^{\text {G12D }}$ Transgenic Models}

Some PDAC models allow to turn on and off the $K$-Ras driver oncogene at will (Collins et al. 2012). These models consist of a transgene that encodes the K-Ras $4 \mathrm{~B}^{\mathrm{G} 12 \mathrm{D}}$ oncoprotein by using a TetO-K-Ras $4 b^{\mathrm{G} 12 \mathrm{D}}$ complementary DNA (cDNA) (Fisher et al. 2001) or the variant construct TetO-LSL-K-Ras $4 b^{\mathrm{G} 12 \mathrm{D}}$ (Ying et al. 2012). Expression of $\mathrm{K}-\mathrm{Ras} 4 \mathrm{~B}^{\mathrm{G} 12 \mathrm{D}}$ requires a reverse tetracycline-controlled transactivator (rtTA), which in these models was knocked in within the Rosa26 locus (R26-LSL-rtTA-IRESEGFP allele) (Belteki et al. 2005). Expression of the rtTA is restricted to pancreatic cells by means of the Ptfla/P48-Cre transgene. The resulting strains, TetO-K-Ras4b ${ }^{\mathrm{G} 12 \mathrm{D}} ; \mathrm{R} 26-L S L$ rtTA-IRES-EGFP;Ptf1a/P48-Cre and TetO-LSLK-Ras $4 b^{\mathrm{G} 12 \mathrm{D}} ; R 26-L S L-r t T A-I R E S-E G F P$; tf1a/ P48-Cre express the K-Ras4B ${ }^{\mathrm{G} 12 \mathrm{D}}$ oncoprotein on exposure to doxycycline leading to the frequent generation of PanIN lesions but not PDAC tumors. Addition of a p53 null (Collins et al. 2012) or floxed (Ying et al. 2012) alleles to these mice resulted in the induction of PDAC with full penetrance. These models have the disadvantage that the levels of $K$-Ras oncogene expression are dictated by the integration site of the TetO-K-Ras $4 b^{\mathrm{G} 12 \mathrm{D}}$ and TetO-LSL-K$R a s 4 b^{\mathrm{G} 12 \mathrm{D}}$ transgenes rather than by the normal $K-R a s$ regulatory sequences. However, they allow the possibility to turn on and off the expression of the K-Rasb ${ }^{\mathrm{G} 12 \mathrm{D}}$ oncoprotein at will. 


\section{Flp/frt-Based Models}

More recently, a new generation of PDAC models has been developed by shifting their dependency from the bacterial Cre/loxP to the yeast $\mathrm{Flp} /$ frt recombinase system. As in the case of the lung tumor models, the use of two independent recombinase systems allows the spatial and temporal separation of tumor development from target ablation/inactivation, an experimental approach essential to evaluate the therapeutic potential of selected targets in preexisting tumors. Saur and colleagues used this dual recombinant system by expressing the Flp recombinase under the control of the $P d x 1$ promoter (Schönhuber et al. 2014). The $P d x 1-F l p$ transgene was incorporated to the $\mathrm{K}-\mathrm{Ras}^{+/ \mathrm{FSFG} 12 \mathrm{D}}$ and $\mathrm{K}$-Ras ${ }^{+/ \mathrm{FSFG}^{2 D}} ; \mathrm{p5} 3^{\text {lox } / \mathrm{lox}}$ strains to recapitulate the $\mathrm{KC}$ and $\mathrm{KPC}$ mice, respectively, originally developed by Tuveson and colleagues (Hingorani et al. 2003, 2005). These strains can be combined with any conditional Cre-based strains such as those that make use of the Tam-dependent CreERT2 or those that express Cre under an inducible promoter to ablate/inactivate those targets whose therapeutic activity needs to be evaluated. In the original model described by Saur and colleagues, the CreERT2 recombinase was part of a CAG-FSF-CreERT2 transgene inserted within

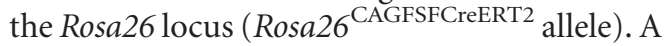
second Rosa26 allele carrying a CAG-LSL-Tomato transgene was added to the model to mark those cells that express an active CreERT2 recombinase on exposure to Tam. Saur and colleagues also developed a variant model in which they incorporate $p 53^{\text {lox }}$ alleles to increase the tumorigenic properties of the KRas ${ }^{\mathrm{G} 12 \mathrm{D}}$ expressing cells. These models, however, have a limitation because the CreERT2 recombinase can only be expressed in those cells derived from the pancreatic precursors that expressed the $P d x 1-F l p$ transgene. Thus, preventing the analysis of potential toxicities caused by the ablation/inactivation of the target in nonpancreatic tissues. This limitation could be easily overcome by using a Rosa26 allele that allows the systemic expression of the Cre-ERT2 recombinase.
We have also developed a variant PDAC model that uses a two-recombinase strategy by replacing the $\mathrm{TetO}$-Cre transgene present in the $K-$ Ras $^{+/ \text {LSLG12Vgeo }}$ Elas- $t$ TA;TetO-Cre mice by a $\mathrm{TetO}-\mathrm{Flp}$ insert. Likewise, the $\mathrm{K}$-Ras ${ }^{\text {LSLG12Vgeo }}$ allele was replaced with a $K-$ Ras $^{\text {FSFG12V }}$ allele (MT Blasco, C Guerra, and M Barbacid, unpubl.). The resulting strain, $K-$ Ras $^{+/ F S F G 12 V}$; Elas-tTA;TetO-Flp, develops PanIN lesions and PDAC with similar incidence and latencies to mice carrying the Cre recombinase. Exposure of pregnant mothers and their offspring to doxycycline can also prevent expression of the oncogene. Finally, addition of $p 53^{\text {frt }}$ alleles to these mice (Lee et al. 2012) allows the rapid development of PDAC tumors with complete penetrance and kinetics similar to those observed in $K$-Ras ${ }^{+/ L_{L L G 12 V g e o}}$ Elas- $t$ TA;TetOCre;p53 $3^{\text {lox/lox }}$ animals. Finally, a ubiquitously expressed hUBC-CreERT2 transgene was added to these mice to allow the ablation/inactivation of targets encoded by their corresponding floxed alleles on Tam exposure.

\section{PDAC TUMORS: TARGET VALIDATION}

The above tumor models have been instrumental in identifying targets with therapeutic properties in PDAC tumors (reviewed in Guerra and Barbacid 2013 and Gopinathan et al. 2015). Unfortunately, most of these studies have used strategies in which the target was ablated or inactivated before or at the time of tumor initiation, hence limiting the translational value of these results to a clinical scenario. Yet, targets whose inhibition can prevent or delay tumor development should be taken into consideration for testing in second generation models that allow their inactivation in advanced tumors. A summary of targets known to block or inhibit PanIN/PDAC development when ablated or inactivated at the time of $K$-Ras oncogene expression is shown in Table 4. They include molecules involved in epidermal growth factor receptor (EGFR) signaling (EGFR, ADAM17, Stat3), Notch signaling (Notch2), NF-кB pathway $(\operatorname{Ikk} \beta)$, PI3K/mTOR pathway (p110 $\alpha$, Pdk1, Rictor, mTRAIL-R), actin reorganization (Rac1), lysosomal proteases 
M. Drosten et al.

Table 4. Target validation in tumor initiation models of pancreatic ductal adenocarcinoma (PDAC) driven by K-Ras oncogenes

\begin{tabular}{|c|c|c|c|}
\hline Model & Target & Tumor phenotype & References \\
\hline $\mathrm{K}_{-R a s^{+/ L S L G 12 D}} ; P d x 1-C r e$ & $B m i 1^{\operatorname{lox} / \operatorname{lox}}$ & No PanIN/PDAC & Bednar et al. 2015 \\
\hline K-Ras ${ }^{+/ L S L G 12 D} ; P d x 1-C r e$ & Cathepsin $B^{\text {lox/lox }}$ & $\begin{array}{l}\text { Reduced PanIN } \\
\text { burden }\end{array}$ & $\begin{array}{l}\text { Gopinathan et al. } \\
2012\end{array}$ \\
\hline K-Ras ${ }^{+/ L S L G 12 D} ; P d x 1-C r e$ & $e N O S^{\operatorname{lox} / \operatorname{lox}}$ & $\begin{array}{l}\text { Reduced PanIN/PDAC } \\
\text { formation }\end{array}$ & $\begin{array}{l}\text { Lampson et al. } \\
2012\end{array}$ \\
\hline$K-$ Ras $^{+/ \text {LSLG12D }} ; P d x 1-C r e$ & $I k k \beta^{\operatorname{lox} / \operatorname{lox}}$ & $\begin{array}{l}\text { Reduced PanIN/PDAC } \\
\text { formation }\end{array}$ & $\begin{array}{l}\text { Maniati et al. } \\
2011\end{array}$ \\
\hline K-Ras ${ }^{+/ L S L G 12 D} ; P d x 1-C r e$ & $I k k \beta^{\operatorname{lox} / \operatorname{lox}}$ & $\begin{array}{l}\text { Reduced PanIN/PDAC } \\
\text { formation }\end{array}$ & Ling et al. 2012 \\
\hline K-Ras ${ }^{+/ L S L G 12 D} ; P d x 1-C r e$ & Stat $3^{\operatorname{lox} / \operatorname{lox}}$ & $\begin{array}{l}\text { Reduced PanIN/PDAC } \\
\text { formation }\end{array}$ & $\begin{array}{l}\text { Corcoran et al. } \\
2011\end{array}$ \\
\hline K-Ras ${ }^{+/ L S L G 12 D} ; P d x 1-C r e$ & $m T R A I L-R^{\operatorname{lox} / \mathrm{lox}}$ & $\begin{array}{l}\text { Reduced PanIN/PDAC } \\
\text { formation }\end{array}$ & $\begin{array}{l}\text { von Karstedt et al. } \\
2015\end{array}$ \\
\hline K-Ras ${ }^{+/ L S L G 12 D} ; P t f 1 a / P 48-C r e$ & $E G F R^{\operatorname{lox} / \operatorname{lox}}$ & No PanIN/PDAC & Ardito et al. 2012 \\
\hline $\mathrm{K}_{-\mathrm{Ras}}{ }^{+/ \mathrm{LSLG}_{12 \mathrm{D}}} ; \mathrm{Ptf1a} / \mathrm{P} 48-\mathrm{Cre}$ & $A D A M 17^{\operatorname{lox} / \operatorname{lox}}$ & No PanIN/PDAC & Ardito et al. 2012 \\
\hline K-Ras ${ }^{+/ L S L G 12 D} ;$ Ptf1a/P48-Cre & $\operatorname{Notch} 2^{\operatorname{lox} / \operatorname{lox}}$ & No PanIN/PDAC & Mazur et al. 2010 \\
\hline $\mathrm{K}_{\text {-Ras }}{ }^{+/ \text {LSLG12D }^{2}} ; \mathrm{Ptfla} / \mathrm{P} 48-\mathrm{Cre}$ & Stat $3^{\text {lox } / \text { lox }}$ & $\begin{array}{l}\text { Reduced PanIN/PDAC } \\
\text { formation }\end{array}$ & Fukuda et al. 2011 \\
\hline K-Ras ${ }^{+/ L S L G 12 D} ; P t f 1 a / P 48-C r e$ & Stat $3^{\operatorname{lox} / \operatorname{lox}}$ & $\begin{array}{l}\text { Reduced PanIN/PDAC } \\
\text { formation }\end{array}$ & Lesina et al. 2011 \\
\hline K-Ras ${ }^{+/ L S L G 12 D} ;$ Ptf1a/P48-Cre & Rictor ${ }^{\operatorname{lox} / \operatorname{lox}}$ & $\begin{array}{l}\text { Reduced PanIN/PDAC } \\
\text { formation }\end{array}$ & $\begin{array}{l}\text { Driscoll et al. } \\
2016\end{array}$ \\
\hline K-Ras ${ }^{+/ L S L G 12 D} ; P t f 1 a / P 48-C r e$ & $P d k 1^{\operatorname{lox} / \operatorname{lox}}$ & No PanIN/PDAC & Eser et al. 2013 \\
\hline K-Ras ${ }^{+/ L S L G 12 D} ;$ Elas-CreERT & $I k k \beta^{\operatorname{lox} / \operatorname{lox}}$ & $\begin{array}{l}\text { Reduced PanIN/PDAC } \\
\text { formation }\end{array}$ & $\begin{array}{l}\text { Daniluk et al. } \\
2012\end{array}$ \\
\hline K-Ras ${ }^{+/ \text {LSLG12D }} ;$ p53 ${ }^{+/ \text {LSLR172H}} ; \mathrm{Pd} d x 1-\mathrm{Cre}$ & Rictor $^{\operatorname{lox} / \mathrm{lox}}$ & Increased survival & $\begin{array}{l}\text { Driscoll et al. } \\
2016\end{array}$ \\
\hline K-Ras ${ }^{+/ \text {LSLG12D }} ; p 53^{+/ L S L R 172 H} ; P d x 1-C r e$ & $P i k 3 c a^{\text {loxKD } / \text { loxKD }}$ & $\begin{array}{l}\text { No tumor } \\
\text { development }\end{array}$ & Baer et al. 2014 \\
\hline K-Ras ${ }^{+/ L S L G 12 D} ; p 53^{+/ L S L R 172 H} ; P d x 1-C r e$ & Cathepsin $B^{\text {lox/lox }}$ & Increased survival & $\begin{array}{l}\text { Gopinathan et al. } \\
2012\end{array}$ \\
\hline K-Ras ${ }^{+/ L S L G 12 D} ; p 53^{+/ L S L R 172 H} ; P d x 1-C r e$ & $e N O S^{\operatorname{lox} / \operatorname{lox}}$ & Increased survival & $\begin{array}{l}\text { Lampson et al. } \\
2012\end{array}$ \\
\hline K-Ras ${ }^{+/ \text {LSLG12D }} ; p 53^{+/ \text {LSLR172H }} ; P d x 1-C r e$ & $m T R A I L-R^{\operatorname{lox} / \operatorname{lox}}$ & Increased survival & $\begin{array}{l}\text { von Karstedt et al. } \\
2015\end{array}$ \\
\hline K-Ras ${ }^{+/ L S L G 12 D} ; p 53^{+/ L S L R 172 H} ; P t f 1 a / P 48-C r e$ & $R a c 1^{\text {lox } / \text { lox }}$ & $\begin{array}{l}\text { No tumor } \\
\text { development }\end{array}$ & Wu et al. 2014 \\
\hline $\mathrm{Ras}^{+/ \mathrm{LSLG12D}} ; p 53^{+/ \mathrm{LSLR} 172 \mathrm{H}} ; \mathrm{Ptf1a} /$ P48-Cre & $P i k 3 c a^{\text {lox/lox }}$ & $\begin{array}{l}\text { No tumor } \\
\text { development }\end{array}$ & Wu et al. 2014 \\
\hline K-Ras ${ }^{+/ \text {LSLG12D }} ; p 53^{\text {lox/lox }} ;$ Ptf1a/P48-Cre & $E G F R^{\operatorname{lox} / \mathrm{lox}}$ & $\begin{array}{r}\text { Delayed tumor } \\
\text { development }\end{array}$ & Ardito et al. 2012 \\
\hline K-Ras ${ }^{+/ \text {LSLG12D }_{2}} ;$ Ink $4 a / A r f^{-/-} ; P d x 1-C r e$ & $B m i 1^{\operatorname{lox} / \operatorname{lox}}$ & Lack of PDAC rescue & Bednar et al. 2015 \\
\hline K-Ras ${ }^{+/ L S L G 12 D} ; I n k 4 a / A r f^{\text {dox } / \text { lox }} ; P d x 1-C r e$ & $I k k \beta^{\operatorname{lox} / \operatorname{lox}}$ & $\begin{array}{l}\text { Reduced PanIN/PDAC } \\
\text { formation }\end{array}$ & Ling et al. 2014 \\
\hline K-Ras ${ }^{+/ \text {LSLG12Vgeo }} ;$ Elas- $t$ TA;TetO-Cre & $E G F R^{\operatorname{lox} / \text { lox }}$ & No PanIN or PDAC & Navas et al. 2012 \\
\hline K-Ras ${ }^{+/ \text {LSLG12Vgeo }} ; p 53^{\text {lox } / \text { lox }} ;$ Elas-tTA;TetO-Cre & $E G F R^{\operatorname{lox} / \text { lox }}$ & $\begin{array}{r}\text { Delayed tumor } \\
\text { development }\end{array}$ & Navas et al. 2012 \\
\hline
\end{tabular}


(CathepsinB), ROS-related molecules (eNOS), and epigenetic regulators (Bmi1) (Table 4). So far, there are no studies in which targets have been validated in advanced established tumors possibly because of the recent generation of the two-recombinase models described above. Schönhuber et al. (2014) ablated expression of the Pdk1 kinase in PanIN containing young mice. Examinations of these animals 6 months later revealed the almost complete disappearance of these lesions. Whether Pdk1 ablation or inactivation will have a similar therapeutic effect in advanced PDAC remains to be determined.

K-RAS is considered to be a "nondruggable target" with the possible exception of the K-RAS ${ }^{\mathrm{G} 12 \mathrm{C}}$ isoform (Ostrem et al. 2013; Patricelli et al. 2016). Yet, it is of significant interest to determine whether direct targeting of this oncoprotein will result in complete tumor regression. Removal of doxycycline exposure results in significant tumor regression in both TetO-K-Ras4b $b^{\mathrm{G} 12 \mathrm{D}} ; R 26-L S L-r t T A-$ IRES-EGFP;Ptfla/P48-Cre and TetO-LSL-KRas $4 b^{\mathrm{G} 12 \mathrm{D}}$;R26-LSL-rtTA-IRES-EGFP; Ptf1a/ P48-Cre mice (Collins et al. 2012; Ying et al. 2012). However, prolonged observation of these tumors revealed that as many as $70 \%$ of them relapsed between 2 and 10 months. Whereas half of these relapsed tumors reexpressed the $K-R a s 4 b^{\mathrm{G} 12 \mathrm{D}}$ oncogene, the other half harbors other oncogenic insults, including Yap1 amplification (Kapoor et al. 2014). Thus, indicating that even effective inhibition of K-RAS, the initial event in PDAC development, may not be sufficient to induce the complete and permanent regression of these tumors.

\section{PHARMACOLOGICAL STUDIES}

GEM PDAC models have also been instrumental in pharmacological studies. The fact that these tumors display the same histological features as human tumors, including the formation of an abundant desmoplastic stroma, makes them more informative than classical xenograft or even PDX models. Some of these studies include those involving the $\gamma$-secretase inhibitor, MRK-003, which blocked PanIN formation in KPC mice treated at very early stages
(Plentz et al. 2009). In PDAC-bearing mice, this inhibitor, in combination with gemcitabine, induced increased survival (nine vs. 26 days). In a more recent study, Tuveson and colleagues (Chio et al. 2016) treated KPC mice with an AKT inhibitor (MK2206) and an inhibitor of glutathione biosynthesis (BSO), a combination that mimics Nfr2 down-regulation. In a weeklong treatment, the combination slowed down tumor growth but did not cause tumor regression. Whether longer treatments will have a more profound therapeutic effect remains to be determined. Treatment of advanced PDACbearing KPC mice with JQ1, a BET inhibitor, in combination with the HDAC inhibitor SAHA, led to a significant increase in survival (15-47 days) (Mazur et al. 2015). More importantly, none of the treated mice died of PDAC. Indeed, histological analysis only revealed residual tumor clusters. Similar results were obtained in a related PDAC tumor model in which the $p 53$ conditional alleles were replaced by those of the Ink4a/Arf locus (Mazur et al. 2015).

\section{TARGETING THE STROMA}

GEM tumor models have also been used to ascertain the role of the desmoplastic stroma in PDAC. Although it has been generally accepted that the stroma enhances PDAC growth, two recent studies performed in KPC mice suggest that inhibiting the stroma may result in more aggressive pancreatic cancer (Ozdemir et al. 2014; Rhim et al. 2014). As expected, ablation of $S h h$ in pancreatic cells $\left(K-R_{a s}{ }^{+/ L S L G 12 D}\right.$; $p 53^{+/ \text {lox }} ; P d x 1$-Cre mice) resulted in a significant decrease in desmoplastic stroma. Yet, the PDAC tumors were more aggressive and significantly decreased survival of these mice. These results have been interpreted as evidence that inhibition of the desmoplastic stroma contributes rather than inhibits tumor development. However, it is also possible that loss of Shh may alter the tumorigenic properties of the tumor cells in a cell-autonomous manner. In the second study, Ozdemir et al. (2014) use the K-Ras ${ }^{+/ L_{L L G 12 D}} ; \mathrm{Tgfbr} 2^{\text {lox/lox}} ; \mathrm{Ptf1a}$-Cre model to ablate cancer-associated fibroblasts (CAFs), the main cellular component of the 
M. Drosten et al.

desmoplastic stroma, using a $\mathrm{TK}^{+} /$ganciclovir strategy. Ablation of CAFs resulted in the death of the mice caused by pulmonary emphysema, thus precluding from establishing a direct correlation between the reduction in CAFs and PDAC-dependent survival. Yet, analysis of the tumors appeared to indicate a more aggressive phenotype. In support of these studies, pharmacological inhibition of stromal cells using the smoothened inhibitor IPI-926 favored tumor progression and reduced survival (Rhim et al. 2014). These results, however, are at variance with a previous study in which treatment of KPC mice with the same compound allowed improved gemcitabine delivery and increased therapeutic efficacy (Olive et al. 2009).

In a different set of studies, exposure of KPC mice to a new paclitaxel formulation (nanoparticle albumin-bound [nab]-paclitaxel), in combination with gemcitabine, slowed tumor growth and in some cases induced tumor regression (Frese et al. 2012; Alvarez et al. 2013). Interestingly, the advantage of this formulation appears to be primarily caused by a decrease in the main gemcitabine-metabolizing enzyme, cytidine deaminase, rather than an effect on the stroma (Frese et al. 2012).

The desmoplastic stroma of PDAC tumors is rich in glycosaminoglycan hyaluronan (HA), a property that may prevent drugs from reaching the tumor cells (Toole et al. 2008). Treatment of KPC mice with PEGPH20, a PEGylated human recombinant $\mathrm{PH} 20$ hyaluronidase, in combination with gemcitabine, led to inhibition of PDAC tumor growth and prolonged survival (Provenzano et al. 2012; Jacobetz et al. 2013). Based on these studies, several clinical trials combining PEGPH20 with gemcitabine have already been initiated.

Regardless of whether the desmoplastic stroma has pro- or antitumoral effects, this tissue clearly serves as a barrier for $\mathrm{T}$ cells, thus preventing the potential use of checkpoint inhibitors, such as anti-CTLA4 or anti-PD1 antibodies, to treat PDAC patients. In a recent study, Feig and colleagues (2013) observed that CAF depletion allowed checkpoint antagonists to control tumor growth. The inhibitory activity of CAFs was mediated by the chemokine
CXCL12, because treatment of KPC mice with a CXCL12 receptor inhibitor, AMD3100, induced the rapid accumulation of $\mathrm{T}$ cells among the tumor cells and acted synergistically with an antibody against the PD1 ligand, PD1-L1 (Feig et al. 2013). Whether these strategies can be successfully translated to the clinic remains to be determined.

\section{CONCLUDING REMARKS}

Several challenges need to be resolved before the results obtained with GEM tumor models, such as those summarized here, can smoothly and steadily reach the clinic. First of all, target or drug validation studies have to be routinely performed in tumor-bearing mice, ideally harboring advanced or metastatic tumors. In addition, target ablation/inactivation should take place systemically and not only in the tumor cells or in selected tissues to mimic future studies with selected inhibitors. In pharmacological studies, it is essential to take into consideration the differential susceptibility to secondary toxic effects of humans versus rodents (e.g., MEK inhibitors) as well as their distinct pharmacodynamic and pharmacokinetic properties.

Another challenge involves the need to carry out combination studies. The mutational load of most human tumors strongly suggests that the successful use of precision medicine will require interference with several targets, either at the same time or sequentially. Use of single targeted therapies (erlotinib, vemurafenib, etc.) has already highlighted their weaknesses: mainly incomplete responses and appearance of resistance mechanisms. Combination studies in GEM tumor models will represent an important challenge for genetic strategies caused by the already significant complexity of the GEM strains. Along the same lines, future target validation experiments should make use of conditional knocked-in alleles in which targets are inactivated (e.g., by expressing a kinase dead isoform) rather than ablated as with standard conditional floxed alleles, because, as of today, protein ablation cannot be achieved by standard medicinal chemistry. It will also be important that future target validations studies, either ge- 
netic or pharmacological, give more attention to the ultimate outcome of their results. A $50 \%$ or even an $80 \%$ decrease in tumor size in a GEM tumor model may have little value in the clinic, where these responses can be often obtained with classical chemotherapy treatments. Likewise, results that yield increased survival by a few days or weeks may not represent significant benefits if translated to human patients.

Finally, we should always keep in mind that no matter how similar GEM tumor models are to the human disease, mouse tumors are considerably smaller, they take less time to develop, and have a more limited mutational load. In any case, we hope that studies using GEM tumor models such as those summarized here will become an indispensable tool in preclinical studies and serve to streamline the translation of novel therapeutic strategies into future clinical trials.

\section{ACKNOWLEDGMENTS}

This work is supported by grants from the European Research Council (ERC-ADG/695566THERACAN), the Spanish Ministry of Economy and Competitiveness (SAF2014-59864-R), and the Spanish Association against Cancer (AECC, GC16173694BARB).

\section{REFERENCES}

Aguirre AJ, Bardeesy N, Sinha M, Lopez L, Tuveson DA Horner J, Redston MS, DePinho RA. 2003. Activated Kras and Ink4a/Arf deficiency cooperate to produce metastatic pancreatic ductal adenocarcinoma. Genes Dev 17: 3112-3126.

Alvarez R, Musteanu M, Garcia-Garcia E, Lopez-Casas PP, Megias D, Guerra C, Muñoz M, Quijano Y, Cubillo A, Rodriguez-Pascual J, et al. 2013. Stromal disrupting effects of nab-paclitaxel in pancreatic cancer. Br J Cancer 109: $926-933$

Ambrogio C, Gómez-López G, Falcone M, Vidal A, Nadal E, Crosetto N, Blasco RB, Fernández-Marcos PJ, SánchezCéspedes M, Ren X, et al. 2016. Combined inhibition of DDR1 and Notch signaling is a therapeutic strategy for KRAS-driven lung adenocarcinoma. Nat Med 22: 270277.

Ardito CM, Gruner BM, Takeuchi KK, Lubeseder-Martellato C, Teichmann N, Mazur PK, DelGiorno KE, Carpenter ES, Halbrook CJ, Hall JC, et al. 2012. EGF receptor is required for KRAS-induced pancreatic tumorigenesis. Cancer Cell 22: 304-317.
Baer R, Cintas C, Dufresne M, Cassant-Sourdy S, Schönhuber N, Planque L, Lulka H, Couderc B, Bousquet C, Garmy-Susini B, et al. 2014. Pancreatic cell plasticity and cancer initiation induced by oncogenic Kras is completely dependent on wild-type PI 3-kinase p $110 \alpha$. Genes Dev 28: $2621-2635$.

Bardeesy N, Aguirre AJ, Chu GC, Cheng KH, Lopez LV, Hezel AF, Feng B, Brennan C, Weissleder R, Mahmood U, et al. 2006. Both p16(Ink4a) and the p19(Arf)-p53 pathway constrain progression of pancreatic adenocarcinoma in the mouse. Proc Natl Acad Sci 103: 5947-5952.

Bassères DS, Ebbs A, Levantini E, Baldwin AS. 2010. Requirement of the NK-кB subunit p65/RelA for K-Rasinduced lung tumorigenesis. Cancer Res 70: 3537-3546.

Bednar F, Schofield HK, Collins MA, Yan W, Zhang Y, Shyam N, Eberle JA, Almada LL, Olive KP, et al. 2015. Bmil is required for the initiation of pancreatic cancer through an Ink4a-independent mechanism. Carcinogenesis 36: 730-738.

Belteki G, Haigh J, Kabacs N, Haigh K, Sison K, Costantini F, Whitsett J, Quaggin SE, Nagy A. 2005. Conditional and inducible transgene expression in mice through the combinatorial use of Cre-mediated recombination and tetracycline induction. Nucleic Acids Res 33: e51.

Blasco RB, Francoz S, Santamaría D, Cañamero M, Dubus P, Charron J, Baccarini M, Barbacid M. 2011. C-Raf, but not B-Raf, is essential for development of K-Ras oncogenedriven non-small-cell lung carcinoma. Cancer Cell 19: 112.

Bowman BM, Sebolt KA; Hoff BA, Boes JL, Daniels DL, Heist KA, Galbán CJ, Patel RM, Zhang J, Beer DG, et al. 2015. Phosphorylation of FADD by the kinase CK1 $\alpha$ promotes KRASG12D-induced lung cancer. Sci Signal 8: ra9.

Carretero J, Shimamura T, Rikova K, Jackson AL, Wilkerson MD, Borgman CL, Buttarazzi MS, Sanofsky BA, McNamara KL, Brandstetter KA, et al. 2010. Integrative genomic and proteomic analyses identify targets for Lkb1-deficient metastatic lung tumors. Cancer Cell 17: 547-559.

Carriere C, Seeley ES, Goetze T, Longnecker DS, Korc M. 2007. The Nestin progenitor lineage is the compartment of origin for pancreatic intraepithelial neoplasia. Proc Natl Acad Sci 104: 4437-4442.

Castellano E, Sheridan C, Thin MZ, Nye E, Spencer-Dene B, Diefenbacher ME, Moore C, Kumar MS, Murillo MM, Grönroos E, et al. 2013. Requirement for interaction of PI3-kinase p110 $\alpha$ with Ras in lung tumor maintenance. Cancer Cell 24: 617-630.

Cellurale C, Sabio G, Kennedy NJ, Das M, Barlow M, Sandy P, Jacks T, Davis RJ. 2011. Requirement of c-Jun $\mathrm{NH}_{2-}$ terminal kinase for Ras-initiated tumor formation. $\mathrm{Mol}$ Cell Biol 31: 1565-1576.

Chen Z, Cheng K, Walton Z, Wang Y, Ebi H, Shimamura T, Liu Y, Tupper T, Ouyang J, Li J, et al. 2012. A murine lung cancer co-clinical trial identifies genetic modifiers of therapeutic response. Nature 483: 613-617.

Chio II, Jafarnejad SM, Ponz-Sarvise M, Park Y, Rivera K, Palm W, Wilson J, Sangar V, Hao Y, Ohlund D, et al. 2016. NRF2 promotes tumor maintenance by modulating mRNA translation in pancreatic cancer. Cell 166: 963976. 
M. Drosten et al.

Clohessy JG, Pandolfi PP. 2015. Mouse hospital and co-clinical trial project-from bench to bedside. Nat Rev Clin Oncol 12: 491-498.

Collins MA, Bednar F, Zhang Y, Brisset JC, Galban S, Galban CJ, Rakshit S, Flannagan KS, Adsay NV, di Magliano MP. 2012. Oncogenic Kras is required for both the initiation and maintenance of pancreatic cancer in mice. J Clin Invest 122: 639-653.

Corcoran RB, Contino G, Deshpande V, Tzatsos A, Conrad C, Benes CH, Levy DE, Settleman J, Engelman JA, Bardeesy N. 2011. STAT3 plays a critical role in KRASinduced pancreatic tumorigenesis. Cancer Res 71: 50205029.

Daniluk J, Liu Y, Deng D, Chu J, Huang H, Gaiser S, CruzMonserrate Z, Wang H, Ji B, Logsdon CG. 2012. An NF-кB pathway-mediated positive feedback loop amplifies Ras activity to pathological levels in mice. JClin Invest 122: $1519-1528$

Davidson SM, Papgiannakopoulos T, Olenchock BA, Heyman JE, Keibler MA, Luengo A, Bauer MR, Jha AK, O'Brian JP, Pierce KA, et al. 2016. Environment impacts the metabolic dependencies of Ras-driven non-small cell lung cancer. Cell Metab 23: 517-528.

De La O J, Emerson LL, Goodman JL, Froebe SC, Illum BE, Curtis AB, Murtaugh LC. 2008. Notch and Kras reprogram pancreatic acinar cells to ductal intraepithelial neoplasia. Proc Natl Acad Sci 105: 18907-18912.

Driscoll DR, Karim SA, Sano M, Gay DM, Jacob W, Yu J, Mizukami Y, Gopinathan A, Jodrell DI, Evans TR, et al. 2016. mTORC2 signaling drives the development and progression of pancreatic cancer. Cancer Res 76: 69116923.

Drosten M, Barbacid M. 2016. Modeling K-Ras-driven lung adenocarcinoma in mice: Preclinical validation of therapeutic targets. J Mol Med 94: 121-135.

Engelman JA, Chen L, Tan X, Crosby K, Guimaraes AR, Upadhyay R, Maira M, McNamara K, Perera SA, Song Y, et al. 2008. Effective use of PI3K and MEK inhibitors to treat Kras G12D and PIK3CA H1047R murine lung cancers. Nat Med 14: 1351-1359.

Eser S, Reiff N, Messer M, Seidler B, Gottschalk K, Dobler M, Hieber M, Arbeiter A, Klein S, Kong B, et al. 2013. Selective requirement of PI3K/PDK1 signaling for Kras oncogene-driven pancreatic cell plasticity and cancer. Cancer Cell 23: 406-420.

Eser S, Schnieke A, Schneider G, Saur D. 2014. Oncogenic KRAS signaling in pancreatic cancer. $\mathrm{Br} J$ Cancer 111: 817-822.

Feig C, Jones JO, Kraman M, Wells RJ, Deonarine A, Chan DS, Connell CM, Roberts EW, Zhao Q, Caballero OL, et al. 2013. Targeting CXCL12 from FAP-expressing carcinomaassociated fibroblasts synergizes with anti-PD-L1 immunotherapy in pancreatic cancer. Proc Natl Acad Sci 110: 20212-20217.

Fisher GH, Wellen SL, Klimstra D, Lenczowski JM, Tichelaar JW, Lizak MJ, Whitsett JA, Koretsky A, Varmus HE. 2001. Induction and apoptotic regression of lung adenocarcinomas by regulation of a K-Ras transgene in the presence and absence of tumor suppressor genes. Genes Dev 15: $3249-3262$.

Frese KK, Neesse A, Cook N, Bapiro TE, Lolkema MP, Jodrell DI, Tuveson DA. 2012. nab-Paclitaxel potentiates gemci- tabine activity by reducing cytidine deaminase levels in a mouse model of pancreatic cancer. Cancer Discov 2: 260269.

Fukuda A, Wang SC, Morris JP IV, Folias AE, Liou A, Kim GE, Akira S, Boucher KM, Firpo MA, Mulvihill SJ, et al. 2011. Stat3 and MMP7 contribute to pancreatic ductal adenocarcinoma initiation and progression. Cancer Cell 19: $441-455$.

García-Beccaria M, Martínez P, Méndez-Pertuz M, Martínez S, Blanco-Aparicio C, Cañamero M, Mulero F, Ambrogio C, Flores JM, Megias D, et al. 2015. Therapeutic inhibition of TRF1 impairs the growth of p53-deficient $\mathrm{K}$-RasG12V-induced lung cancer by indiction of telomeric DNA damage. EMBO Mol Med 7: 930-949.

Gidekel-Friedlander SY, Chu GC, Snyder EL, Girnius N, Dibelius G, Crowley D, Vasile E, DePinho RA, Jacks T. 2009. Context-dependent transformation of adult pancreatic cells by oncogenic K-Ras. Cancer Cell. 16: 379389.

Gopinathan A, Denicola GM, Frese KK, Cook N, Karreth FA, Mayerle J, Lerch MM, Reinheckel T, Tuveson DA. 2012. Cathepsin B promotes the progression of pancreatic ductal adenocarcinoma in mice. Gut 61: 877-884.

Gopinathan A, Morton JP, Jodrell DI, Sansom OJ. 2015. GEMMs as preclinical models for testing pancreatic cancer. Dis Model Mech 8: 1185-1200.

Guerra C, Barbacid M. 2013. Genetically engineered mouse models of pancreatic adenocarcinoma. Mol Oncol 7: 232-247.

Guerra C, Mijimolle N, Dhawahir A, Dubus P, Barradas M, Serrano M, Campuzano V, Barbacid M. 2003. Tumor induction by an endogenous K-ras oncogene is highly dependent on cellular context. Cancer Cell 4: 111-120.

Guerra C, Schuhmacher AJ, Cañamero M, Grippo PJ, Verdaguer L, Perez-Gallego L, Dubus P, Sandgren EP, Barbacid M. 2007. Chronic pancreatitis is essential for induction of pancreatic ductal adenocarcinoma by $\mathrm{K}$ Ras oncogenes in adult mice. Cancer Cell 11: 291-302.

Guerra C, Collado M, Navas C, Schuhmacher AJ, Hernandez-Porras I, Canamero M, Rodriguez-Justo M, Serrano M, Barbacid M. 2011. Pancreatitis-induced inflammation contributes to pancreatic cancer by inhibiting oncogene-induced senescence. Cancer Cell 19: 728-739.

Habbe N, Shi G, Meguid RA, Fendrich V, Esni F, Chen H, Feldmann G, Stoffers DA, Konieczny SF, Leach SD, et al. 2008. Spontaneous induction of murine pancreatic intraepithelial neoplasia ( $\mathrm{mPanIN}$ ) by acinar cell targeting of oncogenic Kras in adult mice. Proc Natl Acad Sci 105: 18913-18918.

Hidalgo M. 2010. Pancreatic cancer. N Engl J Med 362: 1605-1617.

Hingorani SR, Petricoin EF, Maitra A, Rajapakse V, King C, Jacobetz MA, Ross S, Conrads TP, Veenstra TD, Hitt BA, et al. 2003. Preinvasive and invasive ductal pancreatic cancer and its early detection in the mouse. Cancer Cell 4: 437-450.

Hingorani SR, Wang L, Multani AS, Combs C, Deramaudt TB, Hruban RH, Rustgi AK, Chang S, Tuveson DA. 2005 $\operatorname{Trp} 53^{R 172 H}$ and Kras ${ }^{G 12 D}$ cooperate to promote chromosomal instability and widely metastatic pancreatic ductal adenocarcinoma in mice. Cancer Cell 7: 469-483. 
Ijichi H, Chytil A, Gorska AE, Aakre ME, Fujitani Y, Fujitani S, Wright CV, Moses HL. 2006. Aggressive pancreatic ductal adenocarcinoma in mice caused by pancreas-specific blockade of transforming growth factor- $\beta$ signaling in cooperation with active Kras expression. Genes Dev 20: $3147-3160$.

Jackson EL, Willis N, Mercer K, Bronson RT, Crowley D, Montoya R, Jacks T, Tuveson DA. 2001. Analysis of lung tumor initiation and progression using conditional expression of oncogenic K-ras. Genes Dev 15: 3243-3248.

Jackson EL, Olive KP, Tuveson DA, Bronson R, Crowley D, Brown M, Jacks T. 2005. The differential effects of mutant p53 alleles on advanced murine lung cancer. Cancer Res 65: $10280-10288$

Jacobetz MA, Chan DS, Neesse A, Bapiro TE, Cook N, Frese KK, Feig C, Nakagawa T, Caldwell ME, Zecchini HI, et al. 2013. Hyaluronan impairs vascular function and drug delivery in a mouse model of pancreatic cancer. Gut 62: 112-120.

Ji H, Ramsey MR, Hayes DN, Fan C, McNamara K, Kozlowski P, Torrice C, Wu MC, Shimamura T, Perera SA, et al. 2007. LKB1 modulates lung cancer differentiation and metastasis. Nature 448: 807-810.

Johnson L, Mercer K, Greenbaum D, Bronson RT, Crowley D, Tuveson DA, Jacks T. 2001. Somatic activation of the $\mathrm{K}$-ras oncogene causes early onset lung cancer in mice. Nature 410: 1111-1116.

Justilien V, Ali SA, Jamieson L, Yin N, Cox AD, Der CJ, Murray NR, Fields AP. 2017. Ect2-dependent rRNA synthesis is required for KRAS-TRP53-driven lung adenocarcinoma. Cancer Cell 31: 256-269.

Kanda M, Matthaei H, Wu J, Hong SM, Yu J, Borges M, Hruban RH, Maitra A, Kinzler K, Vogelstein B, et al. 2012. Presence of somatic mutations in most early-stage pancreatic intraepithelial neoplasia. Gastroenterology 142: $730-733$.

Kapoor A, Yao W, Ying H, Hua S, Liewen A, Wang Q, Zhong Y, Wu CJ, Sadanandam A, Hu B, et al. 2014. Yapl activation enables bypass of oncogenic Kras addiction in pancreatic cancer. Cell 158: 185-197.

Karreth FA, Frese KK, DeNicola GM, Baccarini M, Tuveson DA. 2011. C-Raf is required for the initiation of lung cancer by K-Ras ${ }^{\mathrm{G} 12 \mathrm{D}}$. Cancer Discov 1: 128-136.

Karsli-Uzunbas G, Huo JY, Price S, Teng X, Laddha SV, Khor S, Kalaany NY, Jacks T, Chan CS, Rabinowitz JD, et al. 2014. Autophagy is required for glucose homeostasis and lung tumor maintenance. Cancer Discov 4: 914-927.

Kissil JL, Walmsley MJ, Hanlon L, Haigis KM, Bender Kim CF, Sweet-Cordero A, Eckman MS, Tuveson DA, Capobianco AJ, Tybulewicz VL, et al. 2007. Requirement for Racl in a K-ras induced lung cancer in the mouse. Cancer Res 67: 8089-8094.

Konstantinidou G, Ramadori G, Torti F, Kangasniemi K, Ramirez RE, Cai Y, Behrens C, Dellinger MT, Brekken RA, Wistuba II, et al. 2013. RHOA-FAK is a required signaling axis for the maintenance of KRAS-driven lung adenocarcinomas. Cancer Discov 3: 444-457.

Kumar MS, Hancock DC, Molina-Arcas M, Steckel M, East P, Diefenbacher M, Armenteros-Monterroso E, Lassailly F, Matthews N, Nye E, et al. 2012. The GATA2 transcriptional network is requisite for RAS oncogene-driven nonsmall-cell lung cancer. Cell 149: 642-655.
Kwon MC, Berns A. 2013. Mouse models for lung cancer. Mol Oncol 7: 165-177.

Lampson BL, Kendall SD, Ancrile BB, Morrison MM, Shealy MJ, Barrientos KS, Crowe MS, Kashatus DF, White RR, Gurley SB, et al. 2012. Targeting eNOS in pancreatic cancer. Cancer Res 72: 4472-4482.

Lawrence MS, Stojanov P, Mermel CH, Robinson JT, Garraway LA, Golub TR, Meyerson M, Gabriel SB, Lander ES, Getz G. 2014. Discovery and saturation analysis of cancer genes across 21 tumour types. Nature 505: 495501.

Lee CL, Moding EJ, Huang X, Li Y, Woodlief LZ, Rodrigues RC, Ma Y, Kirsch DG. 2012. Generation of primary tumors with Flp recombinase in FRT-flanked p53 mice. Dis Model Mech 5: 397-402.

Lesina M, Kurkowski MU, Ludes K, Rose-John S, Treiber M, Klöppel G, Yoshimura A, Reindl W, Sipos B, Akira S, et al 2011. Stat $3 /$ Socs 3 activation by IL- 6 transsignaling promotes progression of pancreatic intraepithelial neoplasia and development of pancreatic cancer. Cancer Cell 19: 456-469.

Licciulli S, Avila JL, Hanlon L, Troutman S, Cesaroni M, Kota S, Keith B, Simon MC, Puré E, Radtke F, et al. 2013. Notch1 is required for Kras-induced lung adenocarcinoma and controls tumor cell survival via p53. Cancer Res 73: 5974-5984.

Ling J, Kang Y, Zhao R, Xia Q, Lee DF, Chang Z, Li J, Peng B, Fleming JB, Wang H, et al. 2012. Kras ${ }^{\mathrm{G} 12 \mathrm{D}}$-induced IKK $2 / \beta / N F-\kappa B$ activation by IL- $1 \alpha$ and p62 feedforward loops is required for development of pancreatic ductal adenocarcinoma. Cancer Cell 21: 105-120.

Maitra A, Hruban RH. 2008. Pancreatic cancer. Annu Rev Pathol 3: 157-188.

Manchado E, Weissmueller S, Morris IV JP, Chen CC, Wullenkord R, Lujambio A, de Stanchina E, Poirier JT, Gainor JF, Corcoran RB, et al. 2016. A combinatorial strategy for treating KRAS-mutant lung cancer. Nature 534: 647651.

Maniati E, Bossard M, Cook N, Candido JB, Emami-Shahri N, Nedospasov SA, Balkwill FR, Tuveson DA, Hagemann T. 2011. Crosstalk between the canonical NF-кB and Notch signaling pathways inhibits Ppary expression and promotes pancreatic cancer progression in mice. J Clin Invest 121: 4685-4699.

Maraver A, Fernandez-Marcos PJ, Herranz D, Cañamero M, Muñoz-Martin M, Gómez-Lopez G, Mulero F, Megías D Sanchez-Carbayo M, Shen J, et al. 2012. Therapeutic effect of $\gamma$-secretase inhibition in Kras ${ }^{\mathrm{G} 12 \mathrm{~V}}$-driven nonsmall cell lung carcinoma by derepression of DUSP1 and inhibition of ERK. Cancer Cell 22: 222-234.

Mazur PK, Einwachter H, Lee M, Sipos B, Nakhai H, Rad R, Zimber-Strobl U, Strobl LJ, Radtke F, Klöppel G, et al. 2010. Notch2 is required for progression of pancreatic intraepithelial neoplasia and development of pancreatic ductal adenocarcinoma. Proc Natl Acad Sci 107: 1343813443.

Mazur PK, Reynoird N, Khatri P, Jansen PW, Wilkinson AW, Liu S, Barbash O, Van Aller GS, Huddleston M, Dhanak D, et al. 2014. SMYD3 links lysine methylation of MAP3K2 to Ras-driven cancer. Nature 510: 283-287.

Mazur PK, Herner A, Mello SS, Wirth M, Hausmann S, Sánchez-Rivera FJ, Lofgren SM, Kuschma T, Hahn SA, 
M. Drosten et al.

Vangala D, et al. 2015. Combined inhibition of BET family proteins and histone deacetylases as a potential epigenetics-based therapy for pancreatic ductal adenocarcinoma. Nat Med 21: 1163-1171.

McFadden DG, Politi K, Bhutkar A, Chen FK, Song X, Pirun M, Santiago PM, Kim-Kiselak C, Platt JT, Lee E, et al 2016. Mutational landscape of EGFR-, MYC-, and Krasdriven genetically engineered mouse models of lung adenocarcinoma. Proc Natl Acad Sci 113: E6409-E6417.

Meylan E, Dooley AL, Feldser DM, Shen L, Turk E, Ouyang C, Jacks T. 2009. Requirement for NK- $\kappa$ B signalling in a mouse model of lung adenocarcinoma. Nature 462: 104107.

Morton JP, Jamieson NB, Karim SA, Athineos D, Ridgway RA, Nixon C, McKay CJ, Carter R, Brunton VG, Frame MC, et al. 2010. LKB1 haploinsufficiency cooperates with Kras to promote pancreatic cancer through suppression of p21-dependent growth arrest. Gastroenterology 139: 586-597.

Navas C, Hernandez-Porras I, Schumacher AJ, Sibilia M, Guerra C, Barbacid M. 2012. EGF receptor signaling is essential for K-Ras oncogene-driven pancreatic ductal adenocarcinoma. Cancer Cell 22: 318-330.

Olive KP, Jacobetz MA, Davidson CJ, Gopinathan A, McIntyre D, Honess D, Madhu B, Goldgraben MA, Caldwell ME, Allard D, et al. 2009. Inhibition of Hedgehog signaling enhances delivery of chemotherapy in a mouse model of pancreatic cancer. Science 324: 1457-1461.

Ostrem JM, Peters U, Sos ML, Wells JA, Shokat KM. 2013. K-Ras ${ }^{\text {G12C }}$ inhibitors allosterically control GTP affinity and effector interactions. Nature 503: 548-551.

Ozdemir BC, Pentcheva-Hoang T, Carstens JL, Zheng X, Wu CC, Simpson TR, Laklai H, Sugimoto H, Kahlert C, Novitskiy SV, et al. 2014. Depletion of carcinoma-associated fibroblasts and fibrosis induces immunosuppression and accelerates pancreas cancer with reduced survival. Cancer Cell 25: 719-734.

Padanad MS, Konstantinidou G, Venkateswaran N, Melegari M, Rindhe S, Mitsche M, Yang C, Batten K, Huffman KE, Liu J, et al. 2016. Fatty acid oxidation mediated by Acyl-CoA synthetase long chain 3 is required for mutant KRAS lung tumorigenesis. Cell Rep 16: 1614-1628.

Pan Y, Jiang Y, Tan L, Ravoori MK, Gagea M, Kundra V, Fischer SM, Yang P. 2015. Deletion of cyclooxygenase-2 inhibits K-ras-induced lung carcinogenesis. Oncotarget 6: $38816-38826$.

Patra KC, Wang Q, Bhaskar PT, Miller L, Wang Z, Wheaton W, Chandel N, Laakso M, Muller WJ, Allen EL, et al. 2013. Hexokinase 2 is required for tumor initiation and maintenance and its systemic deletion is therapeutic in mouse models of cancer. Cancer Cell 24: 213-228.

Patricelli MP, Janes MR, Li LS, Hansen R, Peters U, Kessler LV, Chen Y, Kucharski JM, Feng J, et al. 2016. Selective inhibition of oncogenic KRAS output with small molecules targeting the inactive state. Cancer Discov 6: $316-$ 329.

Peschard P, McCarthy A, Leblanc-Dominguez V, Yeo M, Guichard S, Stamp G, Marshall CJ. 2012. Genetic deletion of RALA and RALB small GTPases reveals redundant functions in development and tumorigenesis. Curr Biol 22: $2063-2068$.
Plentz R, Park JS, Rhim AD, Abravanel D, Hezel AF, Sharma SV, Gurumurthy S, Deshpande V, Kenific C, Settleman J, et al. 2009. Inhibition of $\gamma$-secretase activity inhibits tumor progression in a mouse model of pancreatic ductal adenocarcinoma. Gastroenterology 136: 1741-1749.

Provenzano PP, Cuevas C, Chang AE, Goel VK, Von Hoff DD, Hingorani SR. 2012. Enzymatic targeting of the stroma ablates physical barriers to treatment of pancreatic ductal adenocarcinoma. Cancer Cell 21: 418-429.

Puyol M, Martín A, Dubus P, Mulero F, Pizcueta P, Khan G, Guerra C, Santamaría D, Barbacid M. 2010. A synthetic lethal interaction between $\mathrm{K}$-Ras oncogenes and Cdk4 unveils a therapeutic strategy for non-small-cell lung carcinoma. Cancer Cell 18: 63-73.

Pylayeva-Gupta Y, Grabocka E, Bar-Sagi D. 2011. RAS oncogenes: Weaving a tumorigenic web. Nat Rev Cancer 11: 761-774.

Rhim AD, Oberstein PE, Thomas DH, Mirek ET, Palermo CF, Stephen A, Sastra SA, Dekleva EN, Saunders T, Becerra CP, et al. 2014. Stromal elements act to restrain, rather than support, pancreatic ductal adenocarcinoma. Cancer Cell 25: 735-747.

Schönhuber N, Seidler B, Schuck K, Veltkamp C, Schachtler C, Zukowska M, Eser S, Feyerabend TB, Paul MC, Eser P et al. 2014. A next-generation dual-recombinase system for time- and host-specific targeting of pancreatic cancer. Nat Med 20: 1340-1337.

Singh M, Lima A, Molina R, Hamilton P, Clermont AC, Devasthali V, Thompson JD, Cheng JH, Reslan HB, Ho CC, et al. 2010. Assessing therapeutic responses in Kras mutant cancers using genetically engineered mouse models. Nat Biotechnol 28: 585-593.

Sinkevicius KW, Kriegel C, Bellaria KJ, Lee J, Lau AN, Leeman KT, Zhou P, Beede AM, Fillmore CM, Caswell D, et al. 2014. Neurotrophin receptor TrkB promotes lung adenocarcinoma metastasis. Proc Natl Acad Sci 111: 10299-10304.

Skoulidis F, Cassidy LD, Pisupati V, Jonasson JG, Bjarnason H, Eyfjord JE, Karreth FA, Lim M, Barber LM, et al. 2010. Germline Brca2 heterozygosity promotes Kras ${ }^{G 12 D}$-driven carcinogenesis in a murine model of familial pancreatic cancer. Cancer Cell 18: 499-509.

Skoulidis F, Byers LA, Diao L, Papadimitrakopoulou VA, Tong P, Izzo J, Behrens C, Kadara H, Parra ER, Canales JR, et al. 2015. Co-occurring genomic alterations define major subsets of KRAS-mutant lung adenocarcinoma with distinct biology, immune profiles, and therapeutic vulnerabilities. Cancer Discov 5: 860-877.

Soucek L, Whitfield J, Martins CP, Finch AJ, Murphy DJ, Sodir NM, Karnezis AN, Swigart LB, Nasi S, Evan GI. 2008. Modelling Myc inhibition as a cancer therapy. Nature 455: 679-683.

Soucek L, Whitfield JR, Sodir NM, Massó-Vallés D, Serrano E, Karnezis AN, Swigart LB, Evan GI. 2013. Inhibition of Myc family proteins eradicates KRas-driven lung cancer in mice. Genes Dev 27: 504-513.

Svennson RU, Parker SJ, Eichner LJ, Kolar MJ, Wallace M, Brun SN, Lombardo PS, Van Nostrand JL, Hutchins A, Vera L, et al. 2016. Inhibition of acetyl-CoA carboxylase suppresses fatty acid synthesis and tumor growth of nonsmall-cell lung cancer in preclinical models. Nat Med 22: $1108-1119$. 
Toole BP, Slomiany MG. 2008. Hyaluronan: A constitutive regulator of chemoresistance and malignancy in cancer cells. Semin Cancer Biol 18: 244-250.

Tran PT, Shroff EH, Burns TF, Thiyagarajan S, Das ST, Zabuawala T, Chen J, Cho YJ, Luong R, Tamayo P, et al. 2012. Twistl suppresses senescence programs and thereby accelerates and maintains mutant Kras-induced lung tumorigenesis. PLoS Genet 8: e1002650.

Van Nostrand JL, Brisac A, Mello SS, Jacobs SB, Luong R, Attardi LD. 2015. The p53 target gene SIVA enables nonsmall-cell lung cancer development. Cancer Discov 5: 622-635.

Vicent S, Chen R, Sayles LC, Lin C, Walker RG, Gillespie AK, Subramanian A, Hinkle G, Yang X, Saif S, et al. 2010. Wilms tumor 1 (WT1) regulates KRAS-driven oncogenesis and senescence in mouse and human models. J Clin Invest 120: 3940-3952.

von Karstedt S, Conti A, Nobis M, Montinaro A, Hartwig T, Lemke J, Legler K, Annewanter F, Campbell AD, Taraborrelli L, et al. 2015. Cancer cell-autonomous TRAIL-R signaling promotes KRAS-driven cancer progression, invasion, and metastasis. Cancer Cell 27: 561-573.

Wang IC, Ustiyan V, Zhang Y, Cai Y, Kalin TV, Kalinichenko VV. 2014. Foxml transcription factor is required for the initiation of lung tumorigenesis by oncogenic $\operatorname{Kras}^{\mathrm{G} 12 \mathrm{D}}$. Oncogene 33: 5391-5396.

Whittle MC, Izeradjene K, Rani PG, Feng L, Carlson MA, DelGiorno KE, Wood LD, Goggins M, Hruban RH, Chang AE, et al. 2015. RUNX3 controls a metastatic switch in pancreatic ductal adenocarcinoma. Cell. 161: 1345-1360.

Wu CY, Carpenter ES, Takeuchi KK, Halbrook CJ, Peverley LV, Bien H, Hall JC, DelGiorno KE, Pal D, Song Y, et al.
2014. PI3K regulation of RAC1 is required for KRASinduced pancreatic tumorigenesis in mice. Gastroenterology 147: 1405-1416.e7.

Xia Y, Yeddula N, Leblanc M, Ke E, Zhang Y, Oldfield E, Shaw RJ, Verma IM. 2012. Reduced cell proliferation by IKK2 depletion in a mouse lung-cancer model. Nat Cell Biol 14: 257-265.

Xie H, Hanai JI, Ren JG, Kats L, Burgess K, Bhargava P, Signoretti S, Billiard J, Duffy KJ, Grant A, et al. 2014. Targeting lactate dehydrogenase-A inhibits tumorigenesis and tumor progression in mouse models of lung cancer and impacts tumor initiating cells. Cell Metab 19: 795-809.

Ying H, Elpek KG, Vinjamoori A, Zimmerman SM, Chu GC, Yan H, Fletcher-Sananikone E, Zhang H, Liu Y, Wang W, et al. 2011. PTEN is a major tumor suppressor in pancreatic ductal adenocarcinoma and regulates an NF-кB-cytokine network. Cancer Discov. 1: 158-169.

Ying H, Kimmelman AC, Lyssiotis CA, Hua S, Chu GC, Fletcher-Sananikone E, Locasale JW, Son J, Zhang H, Coloff JL, et al. 2012. Oncogenic Kras maintains pancreatic tumors through regulation of anabolic glucose metabolism. Cell 149: 656-670.

Young NP, Crowley D, Jacks T. 2011. Uncoupling cancer mutations reveals critical timing of p53 loss in sarcomagenesis. Cancer Res 71: 4040-4047.

Zhang Z, Newton K, Kummerfeld SK, Webster J, Kirkpatrick DS, Phu L, Eastham-Anderson J, Liu J, Lee WP, et al. 2017. Transcription factor Etv5 is essential for the maintenance of alveolar type II cells. Proc Natl Acad Sci 114: 3903-3908. 


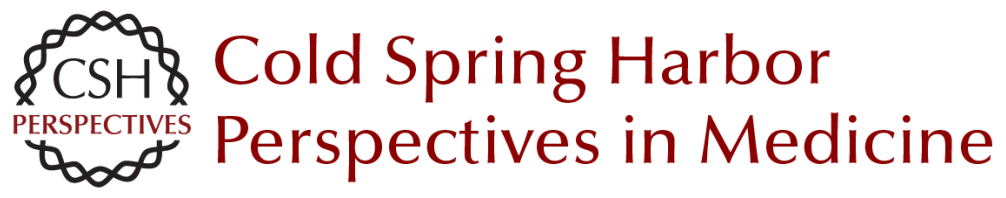

\title{
Genetically Engineered Mouse Models of K-Ras-Driven Lung and Pancreatic Tumors: Validation of Therapeutic Targets
}

\author{
Matthias Drosten, Carmen Guerra and Mariano Barbacid
}

Cold Spring Harb Perspect Med 2018; doi: 10.1101/cshperspect.a031542 originally published online August 4, 2017

\section{Subject Collection Ras and Cancer in the 21st Century}

Targeting Ras with Macromolecules

Dehua Pei, Kuangyu Chen and Hui Liao

Ras-Specific GTPase-Activating Proteins--

Structures, Mechanisms, and Interactions

Klaus Scheffzek and Giridhar Shivalingaiah

Ras-Mediated Activation of the Raf Family

Kinases

Elizabeth M. Terrell and Deborah K. Morrison

Posttranslational Modifications of RAS Proteins lan Ahearn, Mo Zhou and Mark R. Philips

Kras in Organoids

Derek Cheng and David Tuveson

KRAS: The Critical Driver and Therapeutic Target for Pancreatic Cancer

Andrew M. Waters and Channing J. Der

The K-Ras, N-Ras, and H-Ras Isoforms: Unique

Conformational Preferences and Implications for

Targeting Oncogenic Mutants

Jillian A. Parker and Carla Mattos

PI3K: A Crucial Piece in the RAS Signaling Puzzle Agata Adelajda Krygowska and Esther Castellano
MRAS: A Close but Understudied Member of the

RAS Family

Lucy C. Young and Pablo Rodriguez-Viciana

The Interdependent Activation of

Son-of-Sevenless and Ras

Pradeep Bandaru, Yasushi Kondo and John Kuriyan

Targeting the MAPK Pathway in RAS Mutant

Cancers

Sarah G. Hymowitz and Shiva Malek

Ras and the Plasma Membrane: A Complicated

Relationship

Yong Zhou, Priyanka Prakash, Alemayehu A. Gorfe, et al.

Kras and Tumor Immunity: Friend or Foe? Jane Cullis, Shipra Das and Dafna Bar-Sagi

Synthetic Lethal Vulnerabilities in KRAS-Mutant Cancers

Andrew J. Aguirre and William C. Hahn

Efforts to Develop KRAS Inhibitors

Matthew Holderfield

Genetically Engineered Mouse Models of K-Ras-Driven Lung and Pancreatic Tumors:

Validation of Therapeutic Targets

Matthias Drosten, Carmen Guerra and Mariano Barbacid

For additional articles in this collection, see http://perspectivesinmedicine.cshlp.org/cgi/collection/ 